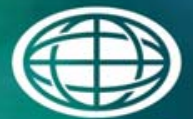

Savannah River

National Laboratory ${ }^{m}$

OPERATED BY SAVANNAH RIVER NUCLEAR SOLUTIONS

\title{
Characterization of a Precipitate Reactor Feed Tank (PRFT) Sample from the Defense Waste Processing Facility (DWPF)
}

Charles L. Crawford

Christopher J. Bannochie

April 2014

SRNL-ST1-2013-00735, Revision 0 


\section{DISCLAIMER}

This work was prepared under an agreement with and funded by the U.S. Government. Neither the U.S. Government or its employees, nor any of its contractors, subcontractors or their employees, makes any express or implied:

1. warranty or assumes any legal liability for the accuracy, completeness, or for the use or results of such use of any information, product, or process disclosed; or

2. representation that such use or results of such use would not infringe privately owned rights; or

3. endorsement or recommendation of any specifically identified commercial product, process, or service.

Any views and opinions of authors expressed in this work do not necessarily state or reflect those of the United States Government, or its contractors, or subcontractors.

\section{Printed in the United States of America}

Prepared for

\section{U.S. Department of Energy}




\section{Characterization of a Precipitate Reactor Feed Tank (PRFT) Sample from the Defense Waste Processing Facility (DWPF)}

Charles L. Crawford

Christopher J. Bannochie

April 2014 


\section{REVIEWS AND APPROVALS}

\section{AUTHORS:}

C. L. Crawford, Process Technology Programs

Date

C. J. Bannochie, Process Technology Programs

Date

TECHNICAL REVIEW:

C. J. Martino, Advanced Characterization \& Process, Reviewed per E7 2.60

Date

APPROVAL:

D. H. McGuire, Manager

Date

Process Technology Programs

S. L. Marra, Manager

Date

Environmental \& Chemical Process Technology Research Programs

E. J. Freed, Manager

Date

DWPF Facility Engineering 
SRNL-STI-2013-00735

Revision 0

\section{EXECUTIVE SUMMARY}

A sample of from the Defense Waste Processing Facility (DWPF) Precipitate Reactor Feed Tank (PRFT) was pulled and sent to the Savannah River National Laboratory (SRNL) in June of 2013. The PRFT in DWPF receives Actinide Removal Process (ARP)/ Monosodium Titanate (MST) material from the 512-S Facility via the 511-S Facility. This $2.2 \mathrm{~L}$ sample was to be used in small-scale DWPF chemical process cell testing in the Shielded Cells Facility of SRNL. A 1L sub-sample portion was characterized to determine the physical properties such as weight percent solids, density, particle size distribution and crystalline phase identification. Further chemical analysis of the PRFT filtrate and dissolved slurry included metals and anions as well as carbon and base analysis.

This technical report describes the characterization and analysis of the PRFT sample from DWPF. At SRNL, the 2.2 L PRFT sample was composited from eleven separate samples received from DWPF. The visible solids were observed to be relatively quick settling which allowed for the rinsing of the original shipping vials with PRFT supernate on the same day as compositing. Most analyses were performed in triplicate except for particle size distribution (PSD), X-ray diffraction (XRD), Scanning Electron Microscopy (SEM) and thermogravimetric analysis (TGA). PRFT slurry samples were dissolved using a mixed $\mathrm{HNO}_{3} / \mathrm{HF}$ acid for subsequent Inductively Coupled Plasma Atomic Emission Spectroscopy (ICPAES) and Inductively Coupled Plasma Mass Spectroscopy (ICP-MS) analyses performed by SRNL Analytical Development (AD).

Per the task request for this work, analysis of the PRFT slurry and filtrate for metals, anions, carbon and base were primarily performed to support the planned chemical process cell testing and to provide additional component concentrations in addition to the limited data available from DWPF. Analysis of the insoluble solids portion of the PRFT slurry was aimed at detailed characterization of these solids (TGA, PSD, XRD and SEM) in support of the Salt IPT chemistry team.

The overall conclusions from analyses performed in this study are that the PRFT slurry consists of 0.61 Wt.\% insoluble MST solids suspended in a $0.77 \mathrm{M}\left[\mathrm{Na}^{+}\right]$caustic solution containing various anions such as nitrate, nitrite, sulfate, carbonate and oxalate. The corresponding measured sulfur level in the PRFT slurry, a critical element for determining how much of the PRFT slurry gets blended into the SRAT, is $0.437 \mathrm{Wt} . \%$ TS. The PRFT slurry does not contain insoluble oxalates nor significant quantities of high activity sludge solids. The lack of sludge solids has been alluded to by the Salt IPT chemistry team in citing that the mixing pump has been removed from Tank $49 \mathrm{H}$, the feed tank to ARP-MCU, thus allowing the sludge solids to settle out. The following conclusions were drawn from the analytical results reported here:

- The PRFT aqueous slurry from DWPF was found to contain $5.96 \mathrm{Wt} \%$ total dried solids. Of these total dried solids, relatively low levels of insoluble solids $(0.61 \mathrm{Wt} . \%)$ were measured. The densities of both the filtrate and slurry were $1.05 \mathrm{~g} / \mathrm{mL}$.

- Particle size distribution of the PRFT solids in filtered caustic simulant and XRD analysis of washed/dried PRFT solids indicate that the PRFT slurry contains a bimodal distribution of particles in the range of 1 and $6 \mu \mathrm{m}$ and that the particles contain sodium titanium oxide hydroxide $\mathrm{Na}_{2} \mathrm{Ti}_{2} \mathrm{O}_{4}(\mathrm{OH})_{2}$ crystalline material as determined by XRD. These data are in excellent agreement with similar data obtained from laboratory sampling of vendor supplied MST. Scanning Electron Microscopy (SEM) combined with Energy Dispersive X-ray Spectroscopy (EDS) analysis of washed/dried PRFT solids shows the particles to be like previous MST analyses consisting of irregular shaped micron-sized solids consisting primarily of Na and Ti. 
- Thermogravimetric analysis of the washed and unwashed PRFT solids shows that the washed solids are very similar to MST solids. The TGA mass loss signal for the unwashed solids shows similar features to TGA performed on cellulose nitrate filter paper indicating significant presence of the deteriorated filter in this unwashed sample. Neither the washed nor unwashed PRFT solids TGA traces showed any features that would indicate presence of sodium oxalate solids.

- The PRFT Filtrate elemental analysis shows that $\mathrm{Na}, \mathrm{S}$ and $\mathrm{Al}$ are major soluble species with trace levels of B, Cr, Cu, K, Li, Si, Tc, Th and U present. Nitrate, nitrite, sulfate, oxalate, carbonate and hydroxide are major soluble anion species. There is good agreement between the analyzed TOC and the total carbon calculated from the sum of oxalate and minor species formate.

- Comparison of the amount and speciation of the carbon species between filtrate and slurry indicates no significant carbon-containing species, e.g., sodium oxalate, are present in the slurry solids.

- Dissolution of the PRFT slurry and subsequent analysis shows that $\mathrm{Na}, \mathrm{Ti}, \mathrm{Si}$ and $\mathrm{U}$ are the major elements present on a Wt.\% total dried solids basis with 30, 5.8 and 0.47 and $0.11 \mathrm{Wt} . \%$ total dried solids, respectively. The amount of Al in the dissolved PRFT slurry is less than that calculated from the PRFT filtrate alone which suggests that the mixed acid digestion used in this work is not optimized for Al recovery. The concentrations of $\mathrm{Ca}, \mathrm{Fe}, \mathrm{Hg}$ and $\mathrm{U}$ are all low (at or below 0.11 wt\%) and there is no detectable Mn or Ni present which indicates no significant HLW sludge solids are present in the PRFT slurry sample. 


\section{TABLE OF CONTENTS}

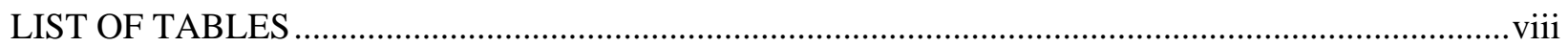

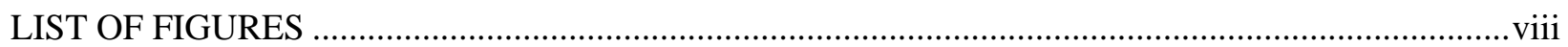

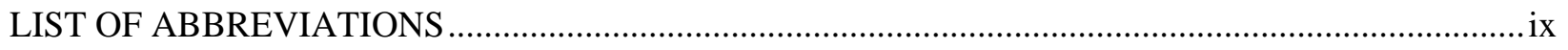

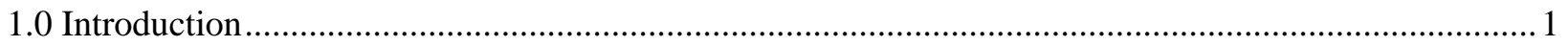

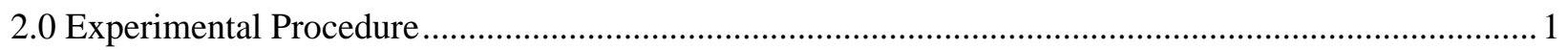

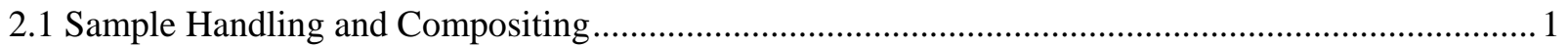

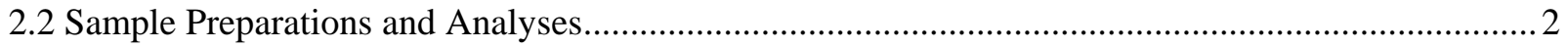

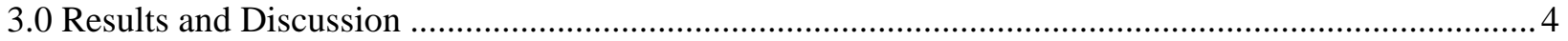

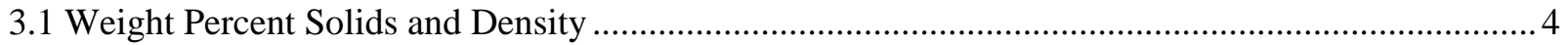

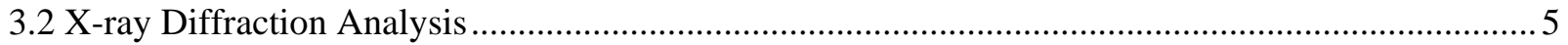

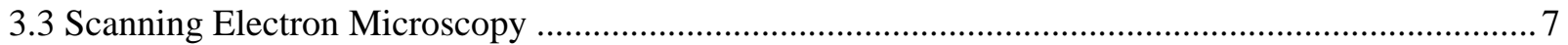

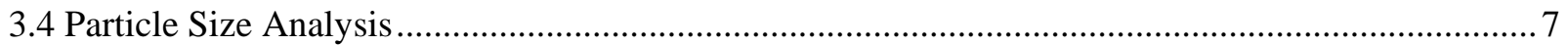

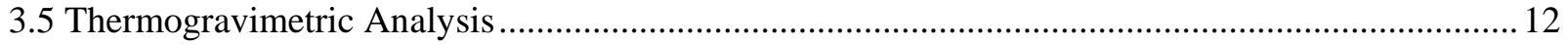

3.6 Filtrate Analysis, Carbon and Total Base Analysis ..................................................................... 15

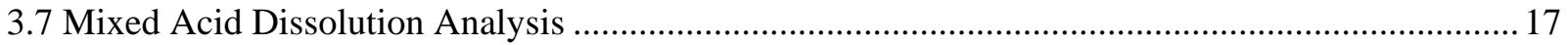

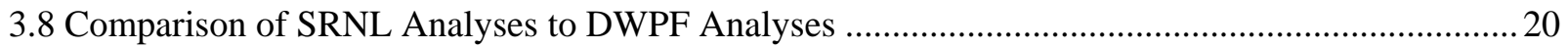

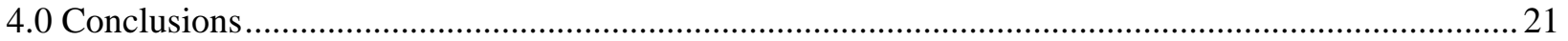

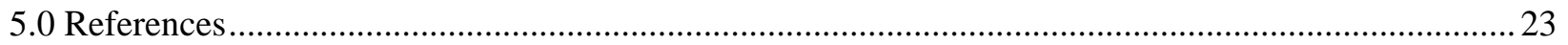

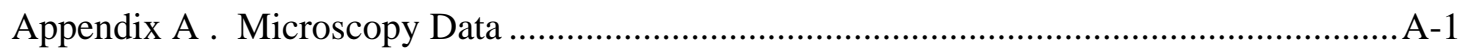




\section{LIST OF TABLES}

Table 3-1. Weight Percent Solids and Density Values for PRFT Slurry [Number of Samples Included in Average]

Table 3-2. PRFT Filtrate Analysis [Number of Samples Included in Average]. 16

Table 3-3. Carbon Analysis for PRFT Filtrate and Slurry [Number of Samples Included in Average] .... 17

Table 3-4. Base Analysis for PRFT Filtrate [Number of Samples Included in Average].........................17

Table 3-5. Elemental and Anion Concentrations in PRFT Slurry in Wt. \% Total Dried Solids [Number of

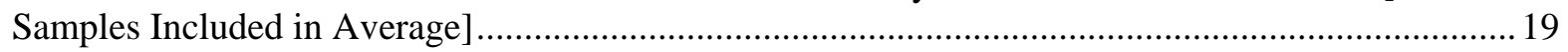

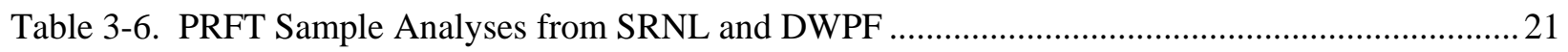

\section{LIST OF FIGURES}

Figure 3-1. XRD spectra of washed PRFT solids sample 1.......................................................... 6

Figure 3-2. XRD spectra of washed PRFT solids sample 2 2............................................................. 6

Figure 3-3. Particle Size Distribution of PRFT Slurry Solids by Volume Distribution............................. 9

Figure 3-4. Particle Size Distribution for MST from Harrell Vendor on Volume Basis ........................... 10

Figure 3-5. Particle Size Distribution for MST from Harrell Vendor on Number Basis ........................... 11

Figure 3-6. TGA Graph Showing Sodium Oxalate, MST and Cellulose Nitrate Filter Paper................... 12

Figure 3-7. TGA Graph Showing (a) Washed Radioactive PRFT Solids and (b) Unwashed Radioactive

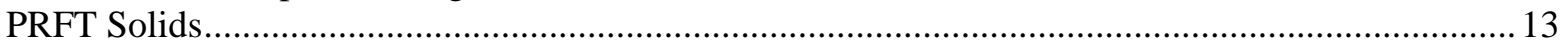

Figure 3-8. TGA Graph Showing Overlay of Washed and Unwashed Radioactive PRFT Solids ........... 14 


\section{LIST OF ABBREVIATIONS}

\begin{tabular}{|c|c|}
\hline AA & Atomic Absorption \\
\hline $\mathrm{AD}$ & Analytical Development \\
\hline ARP & Actinide Removal Process \\
\hline $\mathrm{CC}$ & Cold Chemical \\
\hline CV-AA & Cold Vapor - Atomic Absorption \\
\hline${ }^{\circ} \mathrm{C}$ & Degree Celsius \\
\hline DI & Deionized \\
\hline DWPF & Defense Waste Processing Facility \\
\hline g & Gram \\
\hline HLW & High Level Waste \\
\hline $\mathrm{hr}$ & Hour \\
\hline IC & Ion Chromatography \\
\hline ICP-AES & Inductively Coupled Plasma Atomic Emission Spectroscopy \\
\hline ICP-MS & Inductively Coupled Plasma Mass Spectroscopy \\
\hline IPT & Integrated Project Tem \\
\hline $\mathrm{L}$ & Liter \\
\hline M & Molarity \\
\hline MCU & Modular Caustic-Side Extraction Unit \\
\hline $\mathrm{mg}$ & Milligram \\
\hline $\min$ & Minute \\
\hline $\mathrm{mL}$ & Milliliter \\
\hline $\mathrm{mn}$ & Mean Particle Distribution Associated with the Number Distribution \\
\hline mrem & Milli Roentgen Equivalent in Man \\
\hline MST & Monosodium Titanate \\
\hline mv & Mean Particle Distribution Associated with the Volume Distribution \\
\hline NA & Not Applicable \\
\hline PRFT & Precipitate Reactor Feed Tank \\
\hline PSD & Particle Size Distribution \\
\hline RSD & Relative Standard Deviation \\
\hline SAA & Satellite Accumulation Area \\
\hline SEM/EDS & Scanning Electron Microscopy/Energy Dispersive Spectroscopy \\
\hline SME & Slurry Mix Evaporator \\
\hline SRAT & Sludge Receipt and Adjustment Tank \\
\hline SRNL & Savannah River National Laboratory \\
\hline SRR & Savannah River Remediation \\
\hline TGA & Thermogravimetric Analysis \\
\hline TIC/TOC/TC & Total Inorganic Carbon/ Total Organic Carbon/ Total Carbon \\
\hline TTR & Task Technical Request \\
\hline TS & Total Solids \\
\hline TTQAP & Task Technical and Quality Assurance Plan \\
\hline vol\% & Volume Percent \\
\hline Wt.\% & Weight Percent \\
\hline $\mathrm{W}_{\mathrm{ds}}$ & Weight Percent Dissolved Solids \\
\hline
\end{tabular}




$\begin{array}{ll}\mathrm{W}_{\text {is }} & \text { Weight Percent Insoluble Solids } \\ \mathrm{W}_{\mathrm{ss}} & \text { Weight Percent Soluble Solids } \\ \mathrm{W}_{\text {ts }} & \text { Weight Percent Total Solids } \\ \text { XRD } & \text { X-ray Diffraction }\end{array}$


SRNL-STI-2013-00735

Revision 0

\subsection{Introduction}

A sample of the Precipitate Reactor Feed Tank (PRFT) containing Monosodium Titanate (MST) was sent to the Savannah River National Laboratory (SRNL) from the Defense Waste Processing Facility (DWPF) in June 2013. This sample was provided in order to assist in the investigation of physical properties or 'processability' of the material fed to the DWPF over a range of process variables and to gain further analytical characterization on the PRFT material than had been previously conducted. Processing issues that have negatively impacted waste throughput are described in a DWPF chartered review team report (Handfinger et al., 2013). That review recommended additional testing for processability of various Sludge Receipt and Adjustment Tank (SRAT) and Slurry Mix Evaporator (SME) operating regimes with actual tank waste in an effort to better understand the cause of the processing issues.

SRNL analyses on the PRFT/MST sample were requested by DWPF via Technical Task Request (TTR) STTR-S-00001, Rev. 0. Although the PRFT/MST sample was transmitted to SRNL with applicable analyses that had been performed by DWPF, the TTR requested SRNL to perform additional analyses as required. The PRFT/MST sample analysis is governed by a Task Technical and Quality Assurance Plan (TTQAP) (Lambert, 2013). Analyses included thermogravimetric analysis (TGA), particle size distribution (PSD), Xray diffraction (XRD) and scanning electron microscopy (SEM) and various solids analyses.

In addition to sample characterization to support the DWPF processability issues, the PRFT/MST slurry sample analyses were to also support the Salt Integrated Project Team (IPT) chemistry team issues related to the Actinide Removal Process (ARP) and the Modular Caustic-Side Solvent Extraction Unit (MCU) as described in Wilmarth et al., 2013. That report documents the observations and recommendations for improved operation, increased throughput, and greater reliability of the ARP and the MCU, which remove strontium, actinides, and cesium from retrieved salt waste prior to disposal in saltstone. The Salt IPT report discusses the influence of insoluble oxalate solids and high activity sludge solids on the ARP. A detailed description of how the ARP and MCU process flow sheets interact with the DWPF facility (221-S) and its ancillary facilities (511-S and 512-S) can be found in Fellinger et al., 2007.

Eleven individual samples were collected from the PRFT during the week of June 3, 2013 for a total volume of $2.2 \mathrm{~L}$. The sample vials were packaged for transport inside doorstop shipping containers. The samples were delivered to the SRNL Shielded Cells on June 11, 2013. Initial characterization of the PRFT/MST sample has been reported in a memorandum describing the weight percent solids, density, XRD and SEM/Energy Dispersive Spectroscopy (EDS) and PSD (Crawford, 2013). This technical report further documents the characterization and analyses of the PRFT/MST slurry sample including sample dissolution and subsequent analyses, filtrate analyses and additional PSD analyses.

\subsection{Experimental Procedure}

\subsection{Sample Handling and Compositing}

At SRNL, the PRFT/MST subsamples were transferred from the eleven doorstop shipping containers into a high density polyethylene bottle. A total of 2,336.59 grams of sample was composited from the eleven subsamples that had measured whole body dose rates from the individual vessels in the range of 10 to 50 $\mathrm{mrem} / \mathrm{hr}$ (Crawford, 2013). The content of each vial was poured into the 4-L composite bottle and it was observed that resulting solids in the composite bottle were relatively quick settling. This allowed for some decanted liquid from the composite bottle to be used for rinsing of the individual vials to ensure complete solids removal on the same day as sample compositing (Note: some slower settling slurries, such as highlevel waste (HLW) slurries, are allowed to settle overnight in order to develop a clear supernate portion to 
use as a rinse for solids removal from the vessel). Several vials were rinsed, up to three times, followed by vigorous shaking and subsequent pouring into the composite bottle. Visual observation of the well-rinsed vials indicated no residual sample remained in the original vessels. The PRFT/MST samples were of milky-white appearance with no visible dark solids, i.e., no visible HLW sludge slurry present.

The next day the composite bottle was agitated by vigorous shaking for five minutes after which a pump and tubing was set up for a sample aliquot collection. Both ends of the pump tubing were inserted into the composite bottle and the pump was run for ten minutes for recirculation of the well-mixed sample. The outlet tubing was then placed into a $1 \mathrm{~L}$ polybottle to collect the analytical sample. The remaining $\sim 1.2 \mathrm{~L}$ of sample was archived in a Satellite Accumulation Area (SAA) for future processability testing.

\subsection{Sample Preparations and Analyses}

Weight percent total solids $\left(\mathrm{W}_{\mathrm{ts}}\right)$ and dissolved solids $\left(\mathrm{W}_{\mathrm{ds}}\right)$ measurements were made on subsamples from the PRFT analytical sample according to procedure (Pareizs, 2012). The procedure involves drying known masses of material at $110{ }^{\circ} \mathrm{C}$ until less than $0.005 \mathrm{~g}$ of weight change is measured (typically over a few days) using a calibrated balance capable of weighing to the nearest $0.001 \mathrm{~g}$. Weight percent calcined solids (at $1100{ }^{\circ} \mathrm{C}$ ) was performed on the PRFT slurry and density measurements were performed on both the slurry and supernate per procedure (Bannochie, 2012). Density measurements involve first determining the known volume of a plastic test tube with water at a known temperature using a mass balance on the benchtop. These tubes are then emptied and dried and then placed in the shielded cells and the radioactive sample is added with subsequent mass measurements to the nearest $0.001 \mathrm{~g}$.

Washed solids from the PRFT composite sample were prepared by filtering well-mixed samples with a 0.45 micron filter followed by three separate rinses with $50 \mathrm{~mL}$ of deionized water. Rinsing of filtered solids derived from salt solutions is typically performed to remove any interstitial solids that may result from the filter separation of the supernatant fraction of the slurry. The rinsed solids were allowed to dry over the weekend on the filter with a plastic cover over the solids. These solids were then used to prepare samples for both X-ray diffraction (XRD) and Scanning Electron Microscopy/Energy Dispersive X-ray Spectroscopy (SEM/EDS). Two separate samples were analyzed by XRD consisting of an initial $\sim 0.1 \mathrm{~g}$ solids followed by a second $\sim 0.2$ g solids sample. Two separate samples were also analyzed by SEM/EDS. Microscopy samples were prepared using a SEM aluminum mount fixed with double-sided sticky tape. The mount/tape is touched to the dried solid particles and then placed into a shielded bottle for delivery to the SEM laboratory. Scanning electron microscopy is done with the SRNL LEO-440 digital SEM in a high vacuum, as gas molecules interfere with the electron beam and with the emitted secondary and backscattered electrons used for imaging. Thus particulate specimens for SEM must be prepared for the high-vacuum imaging environment by chemical fixation or coating using an evaporative carbon coating which also serves to make the sample conductive.

A $10 \mathrm{~mL}$ aliquot of the well-mixed slurry from the PRFT subsample was delivered in a shielded bottle to the Particle Size Distribution (PSD) laboratory along with a $250 \mathrm{~mL}$ sample of the PRFT filtrate obtained from filtering the PRFT slurry through a 0.45 micron vacuum filter unit with a nylon filter media. Although the $1 \mathrm{~L}$ PRFT analytical sample was shaken vigorously before sampling, no special preparation was performed on the PRFT slurry, i.e., mechanical mixing/stirring or sonication, before PSD measurements. Analytical Development (AD) personnel indicated that the PSD instrument was unable to obtain a stable background reading with the $250 \mathrm{~mL}$ radioactive PRFT filtrate presumably due to presence of sub-0.45 micron particles in the filtrate. Accordingly, a 0.45 micron filtered simulant containing nominally $0.85 \mathrm{M}$ $\mathrm{NaOH}, 0.065 \mathrm{M} \mathrm{NaNO}_{3}$ and $0.0015 \mathrm{M} \mathrm{NaNO}_{2}$ was used as diluent. 
The PSD measurements were performed on the radioactive PRFT slurry using a Microtrac X-100 diffraction analysis instrument. This instrument quantifies particle diameters based on the portion of light scattered when a laser beam is projected through a fluid containing suspended solid phase particles. The amount and direction of light scattered by the particles is measured by an optical detector array and then analyzed to determine the PSD. The Microtrac X-100 instrument is capable of measuring particles with diameters between 0.7 to $700 \mu \mathrm{m}$. PSD results were reported on a volume distribution basis. Volume distributions provide a means for assessing large particles, since large particles contribute most to the volume. In contrast, number distributions provide a means for evaluating small particles which can be abundant but contribute little to the volume. Mean particle diameters associated with the volume distributions and number distributions were also calculated and reported. The mean particle diameter associated with the volume distribution is denoted as 'mv' and represents the "center of gravity" of the distribution. This quantity is considered the average particle size contributing to the volume. The mean particle diameter associated with the number distribution is denoted as 'mn' and represents the average particle size contributing to the population. The radioactive PRFT slurry PSD is compared to previous PSD data obtained on nonradioactive vendor-supplied MST solids which were obtained using a Microtrac S3500 diffraction analysis instrument capable of measuring particle diameters in the range of 0.243 to $1408 \mu \mathrm{m}$.

PRFT solids were prepared for Thermogravimetric (TGA) analysis by filtering a well-mixed aliquot of the PRFT analytical sample using 0.45 micron cellulose nitrate filters. One sample was washed with copious amounts of deionized water and the other sample was unwashed. These samples were prepared and airdried for several days in the filter cup covered with a plastic cover, it was noticed that the unwashed sample filter media had been severely compromised apparently from interaction with the caustic PRFT slurry. The washed/dried PRFT solids sample for TGA was easily removed from the intact filter for delivery to the TGA laboratory in a shielded bottle. The other unwashed/dried PRFT solids sample for TGA appeared to contain intermixed cellulose nitrate filter fines in its preparation.

TGA was performed on nonradioactive samples of MST, sodium oxalate and cellulose nitrate filter fines. A Setaram Setsys TGA instrument was used with a $10^{\circ} \mathrm{C} / \mathrm{min}$ heat rate up to $900{ }^{\circ} \mathrm{C}$ in an argon purge. Prior to sample analysis a standard calcium oxalate sample was used to functionally verify the TGA instrumentation. These TGA analyses were to gather baseline data on these materials for comparison to the radioactive PRFT solids. The sodium oxalate sample was analyzed since the presence of insoluble sodium oxalate (natroxalate mineral species) has been noted in the 512-S operations (Wilmarth, 2013). Sodium oxalate solubility in aqueous solution is known to have a strong non-linear dependence on total sodium molarity especially below 1M sodium concentration (Ketusky, 2009 and Reynolds, 2008). Sodium oxalate is considered a semi-soluble salt in caustic HLW sludge slurries (Reynolds, 2008, Coleman, 2002a, 2002b). The cellulose nitrate filter fines were analyzed since this material was observed to be intermixed in the unwashed PRFT solids collected for TGA. The washed and unwashed PRFT radioactive solids were analyzed using a Du Pont Instruments TGA instrument with a $10{ }^{\circ} \mathrm{C} / \mathrm{min}$ heat-up rate to $900{ }^{\circ} \mathrm{C}$ in an argon purge. Functional verification of the Du Pont Instruments TGA was also performed with calcium oxalate. TGA measurements for this study focused only on the mass loss vs. temperature profiles. No off-gas analyses from the TGA were performed.

Three separate aliquots of the slurry were digested with a $10 \mathrm{~mL} \mathrm{HNO}_{3} / 2 \mathrm{~mL} \mathrm{HF}$ mixture of acids in sealed Teflon ${ }^{\circledR}$ vessels at $115^{\circ} \mathrm{C}$ for 2 hours using nominal $14 \mathrm{~g}$ slurry with a final water dilution to $100 \mathrm{~mL}$ total volume. The primary aim of these mixed acid digestions was to dissolve the Ti from the MST solids in the PRFT slurry. The sample was digested in triplicate along with a blank for submission to Analytical Development (AD) for the following analyses: atomic absorption spectroscopy (AA) for As, Se, Na and K, cold vapor atomic absorption spectroscopy (CV-AA) analysis for $\mathrm{Hg}$, inductively coupled plasma - atomic emission spectroscopy (ICP-AES) and inductively coupled plasma - mass spectrometry (ICP-MS) for masses 82-208 and 230-244. Elemental sulfur analysis was performed using the ICP-AES in an axial configuration which provides more accurate analysis of relatively low levels of sulfur. 
PRFT well-mixed slurry samples were submitted to AD for ion chromatography (IC) and total inorganic carbon/total organic carbon/total carbon (TIC/TOC/TC). Filtrates derived from the PRFT slurry using 0.45 micron nylon filter media were also submitted to AD for TIC/TOC and total base/free $\mathrm{OH}^{-}$/other base analyses as well as ICP-AES and ICP-MS.

\subsection{Quality Assurance}

Requirements for performing reviews of technical reports and the extent of review are established in manual E7 2.60. SRNL documents the extent and type of review using the SRNL Technical Report Design Checklist contained in WSRC-IM-2002-00011, Rev. 2. Experimental records for all activities described in this memorandum were recorded in the SRNL E-Notebook System by C. J. Bannochie and co-workers (Bannochie, 2013).

\subsection{Results and Discussion}

\subsection{Weight Percent Solids and Density}

Table 3-1 provides the measured and calculated Wt.\% solids values as well as the slurry and supernatant densities and the calcine solids determined for the PRFT subsample. The measured weight percent dissolved solids, $\mathrm{W}_{\mathrm{ds}}$, from the filtrate (5.38 Wt.\%) is $~ 90 \%$ of the measured weight percent total solids, $\mathrm{W}_{\mathrm{ts}}$, from the slurry (5.96 Wt.\%), indicating that relatively small amounts of insoluble solids are present in the MST slurry sample. As indicated in the table, the weight percent soluble solids, $\mathrm{W}_{\mathrm{ss}}$, is calculated by subtracting the weight percent insoluble solids, $\mathrm{W}_{\text {is }}$, from the measured $\mathrm{W}_{\mathrm{ts}}$. The $\mathrm{W}_{\text {is }}(0.61 \pm 0.07 \mathrm{Wt} . \%)$ is calculated using the equation $\mathrm{W}_{\mathrm{is}}=\left(\mathrm{W}_{\mathrm{ts}}-\mathrm{W}_{\mathrm{ds}}\right) /\left(1-\mathrm{W}_{\mathrm{ds}}\right)$, with the measured inputs of $\mathrm{W}_{\mathrm{ts}}$ (average from slurry) and $\mathrm{W}_{\mathrm{ds}}$ (average from filtrate). The $\pm 0.07 \mathrm{Wt} \%$ for $\mathrm{W}_{\mathrm{is}}$ represents the $95 \%$ uncertainty in the calculated $\mathrm{W}_{\text {is }}$ that is determined from error propagation of the quadruplicate data sets for the measured $\mathrm{W}_{\mathrm{ts}}$ and $\mathrm{W}_{\mathrm{ds}}$. 
SRNL-STI-2013-00735

Revision 0

\section{Table 3-1. Weight Percent Solids and Density Values for PRFT} Slurry [Number of Samples Included in Average]

\begin{tabular}{|c|c|}
\hline Property & $\begin{array}{c}\text { PRFT } \\
\text { Subsample } \\
\text { (\% RSD*) }\end{array}$ \\
\hline $\begin{array}{l}\text { Total Solids, } \mathbf{W}_{\text {ts }} \\
\text { (Wt.\% in Slurry) }\end{array}$ & $5.96(0.2)[4]$ \\
\hline $\begin{array}{l}\text { Dissolved Solids, } \mathbf{W}_{\mathrm{ds}} \\
\text { (Wt.\% in Supernate) }\end{array}$ & $5.38(0.8)[4]^{\mathrm{a}}$ \\
\hline $\begin{array}{l}\text { Soluble Solids, } \mathbf{W}_{\text {ss }} \\
\text { (Wt.\% in Slurry) }\end{array}$ & $5.34^{b}$ \\
\hline $\begin{array}{l}\text { Insoluble Solids, } \mathbf{W}_{\text {is }} \\
\text { (Wt.\% in Slurry) }\end{array}$ & $0.61 \pm 0.07^{\mathrm{c}}$ \\
\hline $\begin{array}{l}\text { Calcine Solids } \\
\text { (Wt.\% in Slurry) }\end{array}$ & $2.82(4.0)[4]$ \\
\hline $\begin{array}{l}\text { Slurry Density } \\
\text { (g/mL) }\end{array}$ & $1.049(0.3)[4]$ \\
\hline $\begin{array}{l}\text { Supernate Density } \\
(\mathrm{g} / \mathrm{mL})\end{array}$ & $1.048(0.3)[4]$ \\
\hline \multicolumn{2}{|c|}{$\begin{array}{l}\text { \%RSD values are relative to the true calculated averages of the } \\
\text { quantities in the table, while the average values reported have } \\
\text { been rounded off to a reasonable number of significant figures. } \\
\text { Measured value also known as Uncorrected Soluble Solids. } \\
\text { Calculated from the average } \mathrm{W}_{\mathrm{ts}} \text { and } \mathrm{W}_{\mathrm{is}} \text { values, also known as } \\
\text { Corrected Soluble Solids. } \\
\text { Average } \mathrm{W}_{\text {is }} \text { calculated from the average } \mathrm{W}_{\mathrm{ts}} \text { and } \mathrm{W}_{\mathrm{ds}} \text { values } \\
\text { The } \pm \text { deviation calculated from error propagation of } \mathrm{W}_{\mathrm{ts}} \text { and } \\
\mathrm{W}_{\mathrm{ds}} \text { replicates. }\end{array}$} \\
\hline
\end{tabular}

\subsection{X-ray Diffraction Analysis}

Figure 3-2 shows the XRD spectra for the $0.1 \mathrm{~g}$ washed/dried sample and Figure 3-2 shows the XRD spectra for the $0.2 \mathrm{~g}$ washed/dried sample. These spectra show the single crystalline species present identified by best match with crystalline structure database as sodium titanium oxide hydroxide $\left(\mathrm{Na}_{2} \mathrm{Ti}_{2} \mathrm{O}_{4}(\mathrm{OH})_{2}\right)$. This formula contains the same elemental ratios as for monosodium titanate $\left(\mathrm{Na}^{+} \mathrm{TiO}_{3} \mathrm{H}^{-}\right)$. These spectra are an excellent match to the Monosodium Titanate (MST) XRD spectra collected for the vendor supplied MST (Taylor-Pashow, 2012). It should be noted that even though an XRD pattern is observable for MST, it is generally referred to as an 'amorphous or poorly crystalline material' (Hobbs, 2011) with a suggested formula of the amorphous solids as $\mathrm{NaTi}_{2} \mathrm{O}_{5} \mathrm{H}$ (Hobbs, 2005). 


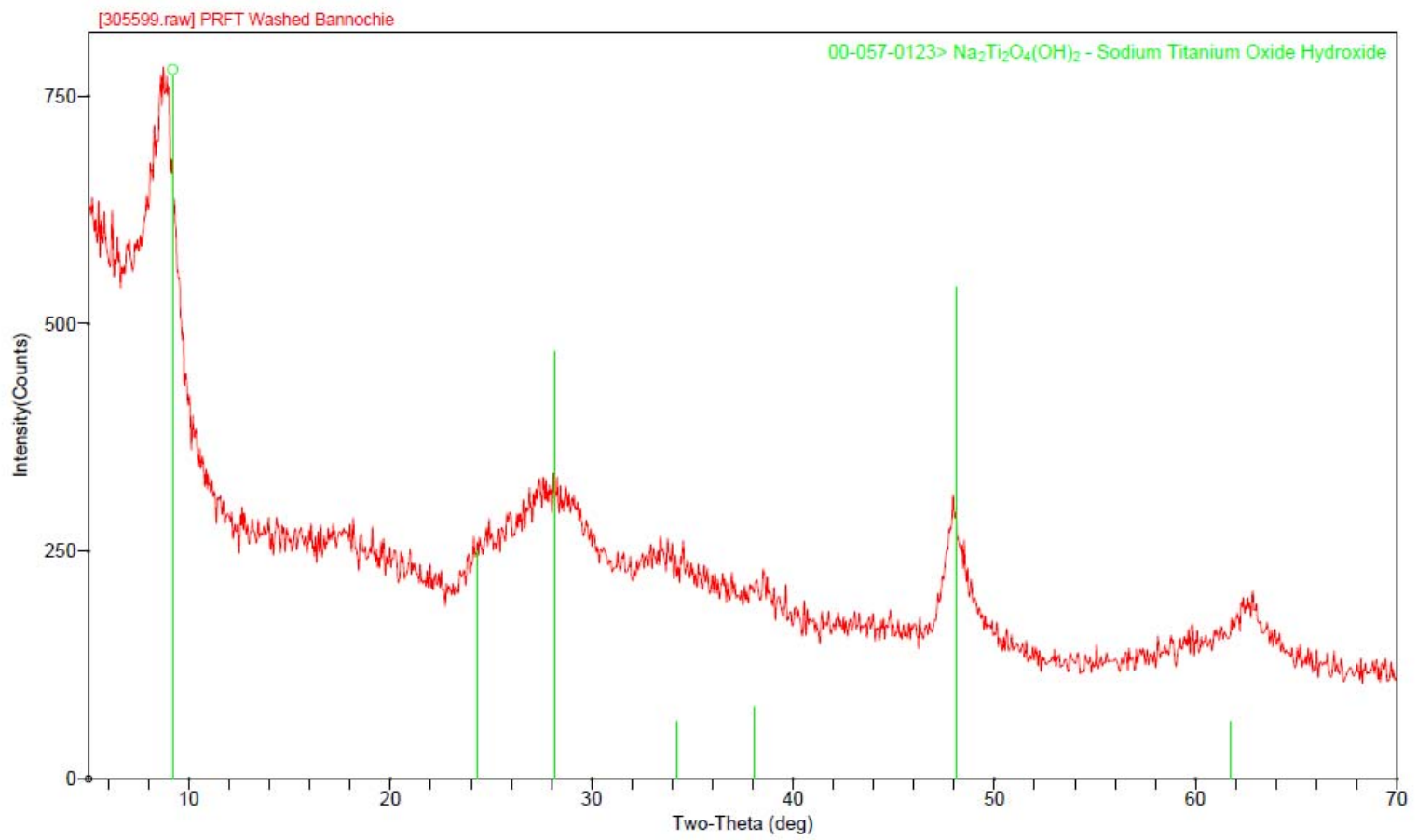

Figure 3-1. XRD spectra of washed PRFT solids sample 1.

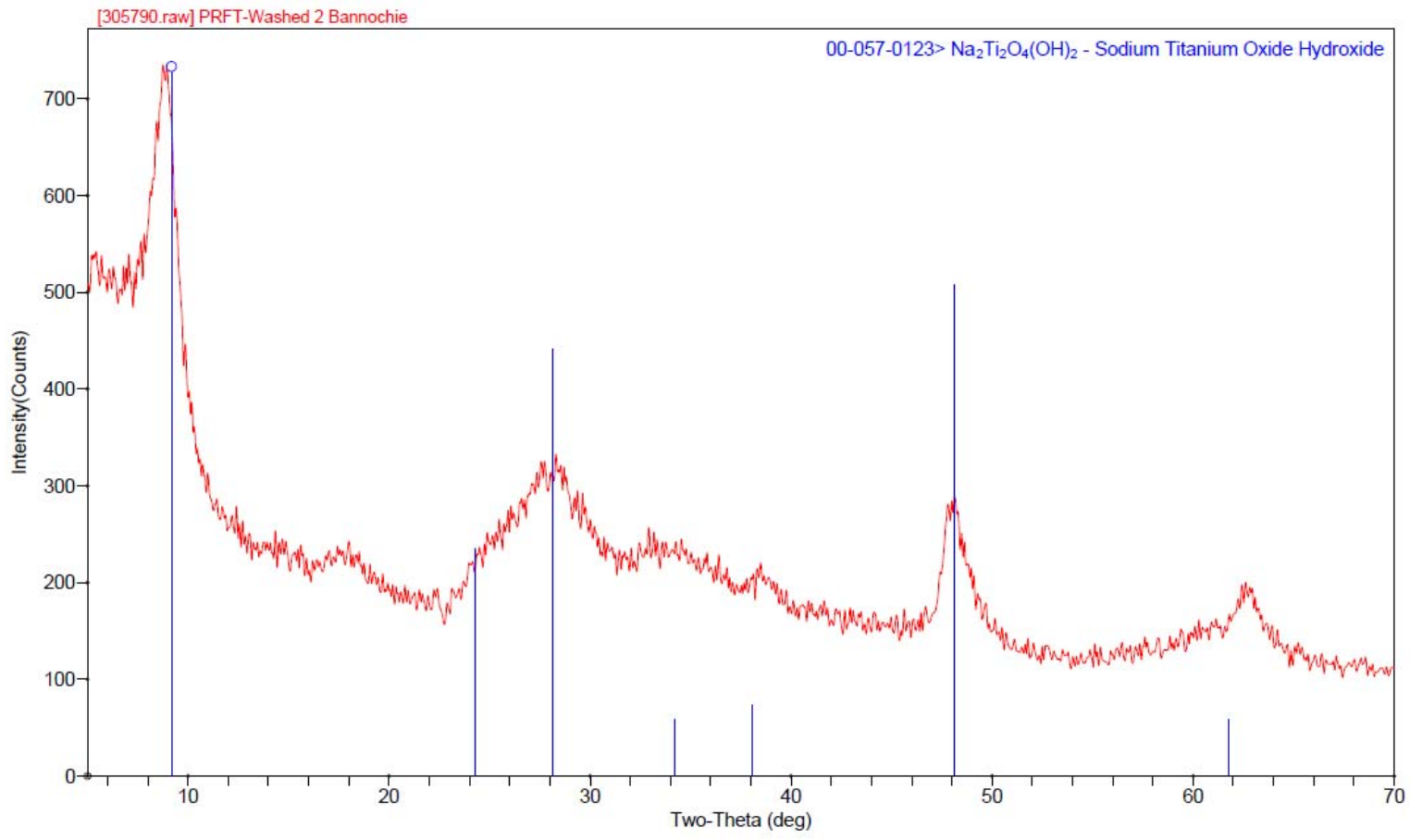

Figure 3-2. XRD spectra of washed PRFT solids sample 2. 


\subsection{Scanning Electron Microscopy}

Appendix A contains SEM images of the washed PRFT solids. These images represent various portions or regions of the PRFT washed solids that were collected on the SEM mount. Figure A- 1 (a) shows the low 17X magnification of PRFT sample 1 and Figure A- 1 (b) shows a small region from Figure A- 1 (a) expanded on a 100X magnification. Similar images for the PRFT sample 2 are shown in Figure A- 2. Both of these two figures show continuous layers of material as well as individual pieces or agglomerates of material of 100 to $200 \mu \mathrm{m}$ in diameter. Figures A-3 through A-8 show more detailed SEM images and EDS spectra from the first PRFT sample and Figures A-9 and A-10 show more detailed SEM images and EDS spectra from the second PRFT sample.

Figure A- 3 shows the micrograph image obtained using 500X magnification of a region within the continuous layer of material and various spots labeled with a ' 1 '. Figure A- 4 shows the EDS spectra associated with the material indicated by the ' 1 ' spots to be primarily $\mathrm{Na}$ and Ti elements with trace levels of Al, U, Ca and Fe present. Figure A- 5 (a) shows images of the individual agglomerates of material at a $100 \mathrm{X}$ magnification and a single agglomerate is magnified to $500 \mathrm{X}$ and $1,000 \mathrm{X}$, respectively in Figure A- 5 (b) and (c). This series of images shows that agglomerates appear to consist of tightly grouped collections of very small micrometer-sized particles. The EDS spectra of the Figure A- 5 (b) spots labeled with a ' 1 ' is shown in Figure A- 6 which indicates primarily $\mathrm{Na}$ and Ti peaks with minor peaks attributed to $\mathrm{Fe}, \mathrm{Al}, \mathrm{Si}$, $\mathrm{Cl}, \mathrm{U}$ and $\mathrm{Ca}$. Figure A- 7 shows the micrograph image obtained using 250X magnification of a region within the continuous layer of material and various spots labeled with a ' 1 '. Figure A- 8 shows the EDS spectra associated with the material indicated by the ' 1 ' spot to be primarily $\mathrm{Na}$ and Ti elements with trace levels of U, Ca and Fe.

Figure A- 9 shows the micrograph image obtained using 500X magnification of a region within the continuous layer of PRFT sample 2 and various spots labeled with a ' 1 ' in the upper image and a micrograph of the same area shown with 1,000X magnification in the lower image. Figure A- 10 shows the EDS spectra associated with the material indicated by the ' 1 ' spot to be primarily $\mathrm{Na}$ and $\mathrm{Ti}$ elements with trace levels of U, Ca and Fe.

These microscopy data of the washed and dried PRFT solids appear to show the expected irregular shaped micron-sized solids that have been previously reported from microscopy analysis of MST (Hobbs, 2011). The micrographs from the highest SEM magnification such as Figure A-3, Figure A-5 (c) and Figure A-9 (b) are the best SEM image examples of these irregular shaped solids. EDS spectra also conclusively show that these solids are comprised primarily of $\mathrm{Na}$ and $\mathrm{Ti}$ as expected for MST solids.

\subsection{Particle Size Analysis}

Figure 3-3 shows the PSD for the radioactive PRFT slurry solids in the simulated (filtered) salt solution on a volume distribution basis. This figure shows that the PRFT solids are distributed in two ranges centered at 1.2 and $6.4 \mu \mathrm{m}$ diameter. The mean particle diameter associated with the volume distribution, mv, is 5.8 and the mean particle diameter associated with the number distribution, $\mathrm{mn}$, is $1.2 \mu \mathrm{m}$. These data, which were collected using a filtered diluent consisting of $0.85 \mathrm{M} \mathrm{NaOH}, 0.065 \mathrm{M} \mathrm{NaNO}$ and $0.0015 \mathrm{M} \mathrm{NaNO}_{2}$, indicate that all particles are less than $20 \mu \mathrm{m}$ in size. Previous initial PSD characterization of the PRFT slurry when performed in DI water as diluent indicated the presence of larger particles of $\sim 200 \mu \mathrm{m}$ as shown in Figure 4 of Crawford, 2013. The current PSD data shown in Figure 3-3 should be more representative of the actual size distributions since this data was derived from a caustic simulant that better matches the actual PRFT solution's chemical composition. 
The current PRFT sample analyzed in caustic simulant does not have an associated PSD measured on a number distribution. Previous number distribution basis data from the PRFT sample performed in DI water diluent, (see Figure 5 of Crawford, 2013) showed a mean particle diameter associated with the number distribution, mn, of 1.04 microns.

The particle size distributions determined for the PRFT slurry solids can be compared to the September 2012 vendor supplied MST from Harrell determined during qualification and verification testing of the material (Taylor-Pashow 2012). Figure 3-4 shows the PSD of MST on a volume basis and Figure 3-5 shows the PSD of MST on a number basis. These PSD analyses were determined in DI water solution and no special preparation was performed on the MST slurry, i.e., mechanical mixing/stirring or sonication, before PSD measurements.

Comparison of the PRFT PSD from Figure 3-3 to the MST PSD in Figure 3-4 shows that the two size ranges for these two materials are very similar (centered around $\sim 1 \mu \mathrm{m}$ and $\sim 6 \mu \mathrm{m}$ ). The MST particles are not expected to have more than 1 vol\% of particles greater than $37 \mu \mathrm{m}$ and not more than 10 vol\% of particles below 0.8 microns per the vendor specifications (Specification for Procurement, 2010).

Both the PRFT slurry solids measured in DI water and the MST solids measured in DI water are similar on a number basis as the mean particle diameters associated with the number distribution are $1.04 \mu \mathrm{m}$ for the PRFT and $0.79 \mu \mathrm{m}$ for the MST. 


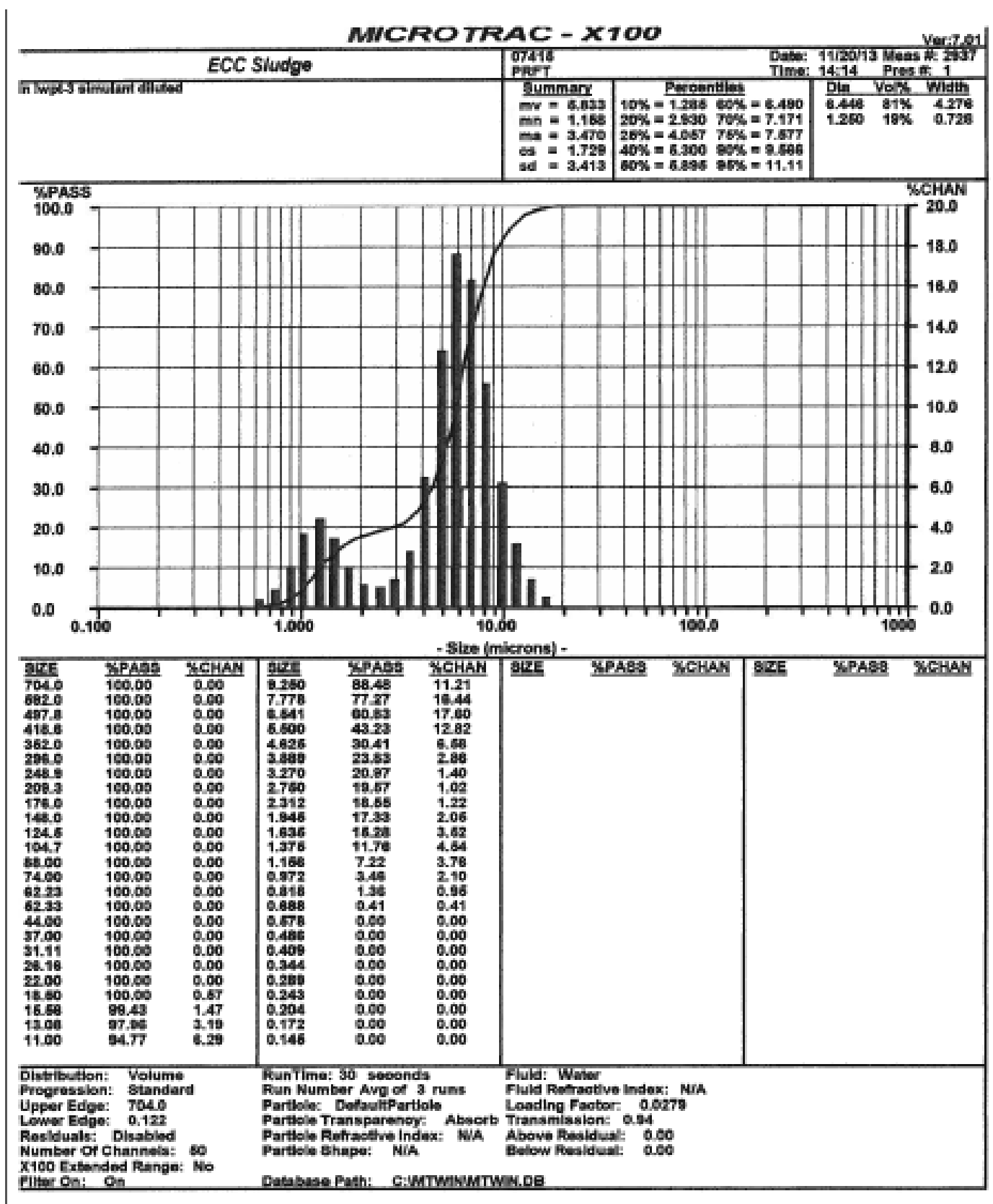

Figure 3-3. Particle Size Distribution of PRFT Slurry Solids by Volume Distribution 
SRNL-STI-2013-00735

Revision 0

\begin{tabular}{|c|c|}
\hline Data Item & Value \\
\hline MV(um): & 5.28 \\
\hline MN(um): & 0.787 \\
\hline MA(um): & 2.841 \\
\hline CS: & 2.112 \\
\hline SD: & 3.1 \\
\hline & \\
\hline
\end{tabular}

\begin{tabular}{|c|c|}
\hline Size(um) & \% Tile \\
\hline 0.800 & 5.53 \\
\hline & \\
\hline & \\
\hline & \\
\hline & \\
\hline & \\
\hline & \\
\hline & \\
\hline & \\
\hline & \\
\hline
\end{tabular}

\begin{tabular}{|c|c|}
\hline$\%$ Tile & Size(um) \\
\hline 10.00 & 1.030 \\
\hline 16.00 & 1.515 \\
\hline 25.00 & 3.53 \\
\hline 40.00 & 4.68 \\
\hline 50.00 & 5.22 \\
\hline 60.00 & 5.77 \\
\hline 70.00 & 6.40 \\
\hline 75.00 & 6.78 \\
\hline 90.00 & 8.76 \\
\hline 95.00 & 10.51 \\
\hline
\end{tabular}

\begin{tabular}{|c|c|c|}
\hline Dia & Vol\% & Width \\
\hline 5.68 & 83.2 & 4.07 \\
\hline 0.944 & 16.8 & 0.66 \\
\hline & & \\
\hline & & \\
\hline & & \\
\hline & & \\
\hline
\end{tabular}

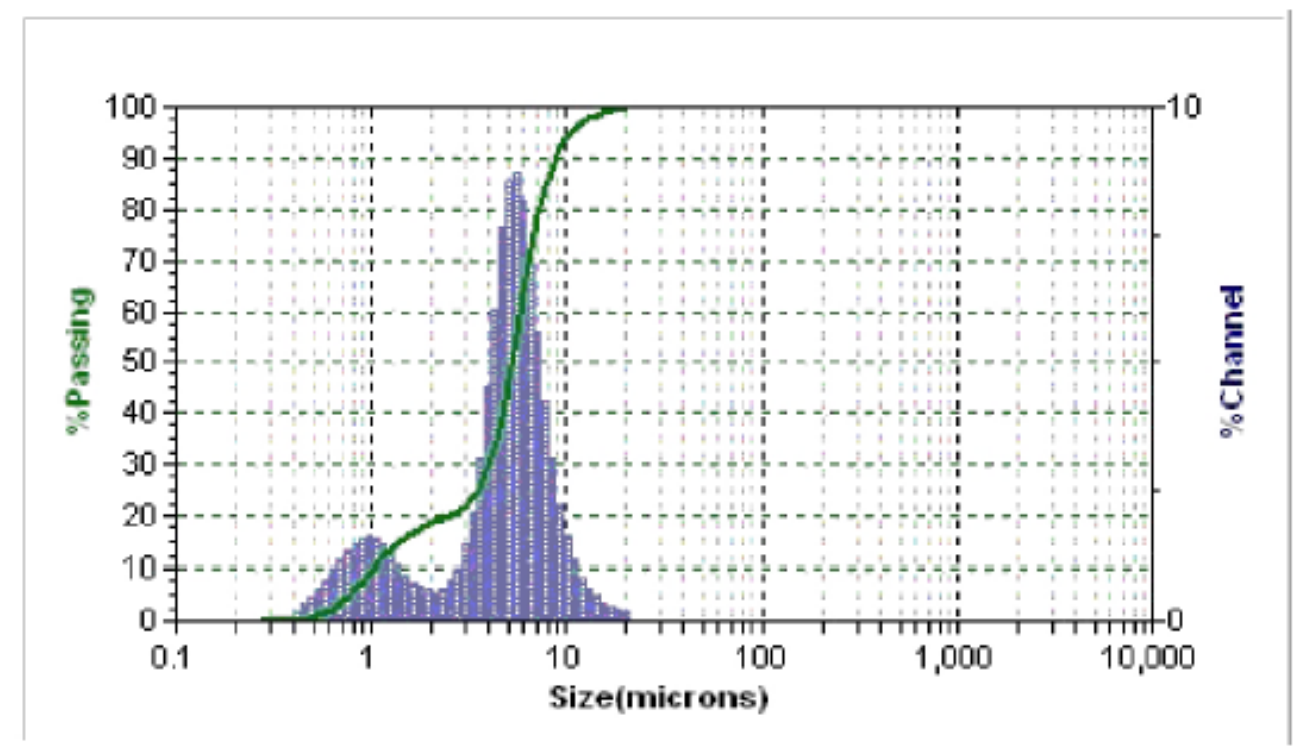

Figure 3-4. Particle Size Distribution for MST from Harrell Vendor on Volume Basis 
SRNL-STI-2013-00735

Revision 0

\begin{tabular}{|c|c|}
\hline Data Item & Value \\
\hline MV (um): & 5.28 \\
\hline MN (um): & 0.787 \\
\hline MA (um): & 2.841 \\
\hline CS: & 2.112 \\
\hline SD: & 0.241 \\
\hline & \\
\hline
\end{tabular}

\begin{tabular}{|l|l|}
\hline Size(um) & \% Tile \\
\hline 0.800 & 70.57 \\
\hline & \\
\hline & \\
\hline & \\
\hline & \\
\hline & \\
\hline & \\
\hline & \\
\hline & \\
\hline & \\
\hline
\end{tabular}

\begin{tabular}{|c|c|}
\hline$\%$ Tile & Size(um) \\
\hline 10.00 & 0.460 \\
\hline 16.00 & 0.484 \\
\hline 25.00 & 0.524 \\
\hline 40.00 & 0.597 \\
\hline 50.00 & 0.651 \\
\hline 60.00 & 0.715 \\
\hline 70.00 & 0.795 \\
\hline 75.00 & 0.844 \\
\hline 90.00 & 1.100 \\
\hline 95.00 & 1.337 \\
\hline
\end{tabular}

\begin{tabular}{|c|c|c|}
\hline Dia & Vol\% & Width \\
\hline 0.651 & 100.0 & 0.48 \\
\hline & & \\
\hline & & \\
\hline & & \\
\hline & & \\
\hline & & \\
\hline
\end{tabular}

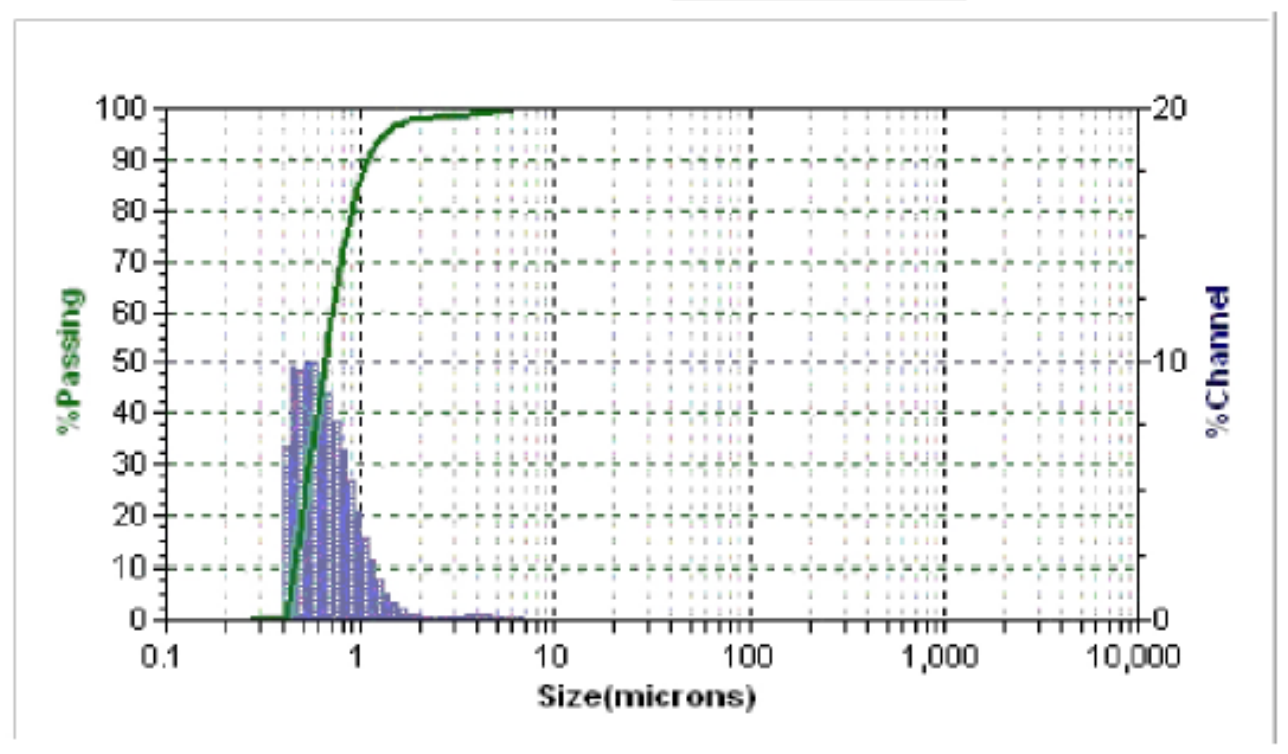

Figure 3-5. Particle Size Distribution for MST from Harrell Vendor on Number Basis 


\subsection{Thermogravimetric Analysis}

Thermogravimetric analyses of the nonradioactive samples are shown in Figure 3-6. These samples included sodium oxalate, MST powder and cellulose nitrate filter paper. The temperature trace for these analyses is shown as a red line increasing from the lower left at room temperature up to the upper right at target $900{ }^{\circ} \mathrm{C}$. Sodium oxalate appears unreactive under these conditions up to a temperature of $\sim 570{ }^{\circ} \mathrm{C}$ where an abrupt $20 \%$ mass change occurs, followed by only a slight few percent of further mass loss up through $900{ }^{\circ} \mathrm{C}$. The MST powder appears to lose $>20 \%$ of mass in the temperature range of 100 to $200{ }^{\circ} \mathrm{C}$ with no further significant mass loss up to $900{ }^{\circ} \mathrm{C}$. The filter paper sample is rapidly consumed showing $>80 \%$ mass loss up to $\sim 175^{\circ} \mathrm{C}$, followed by eventual complete mass loss across the remaining heat up through $900{ }^{\circ} \mathrm{C}$.

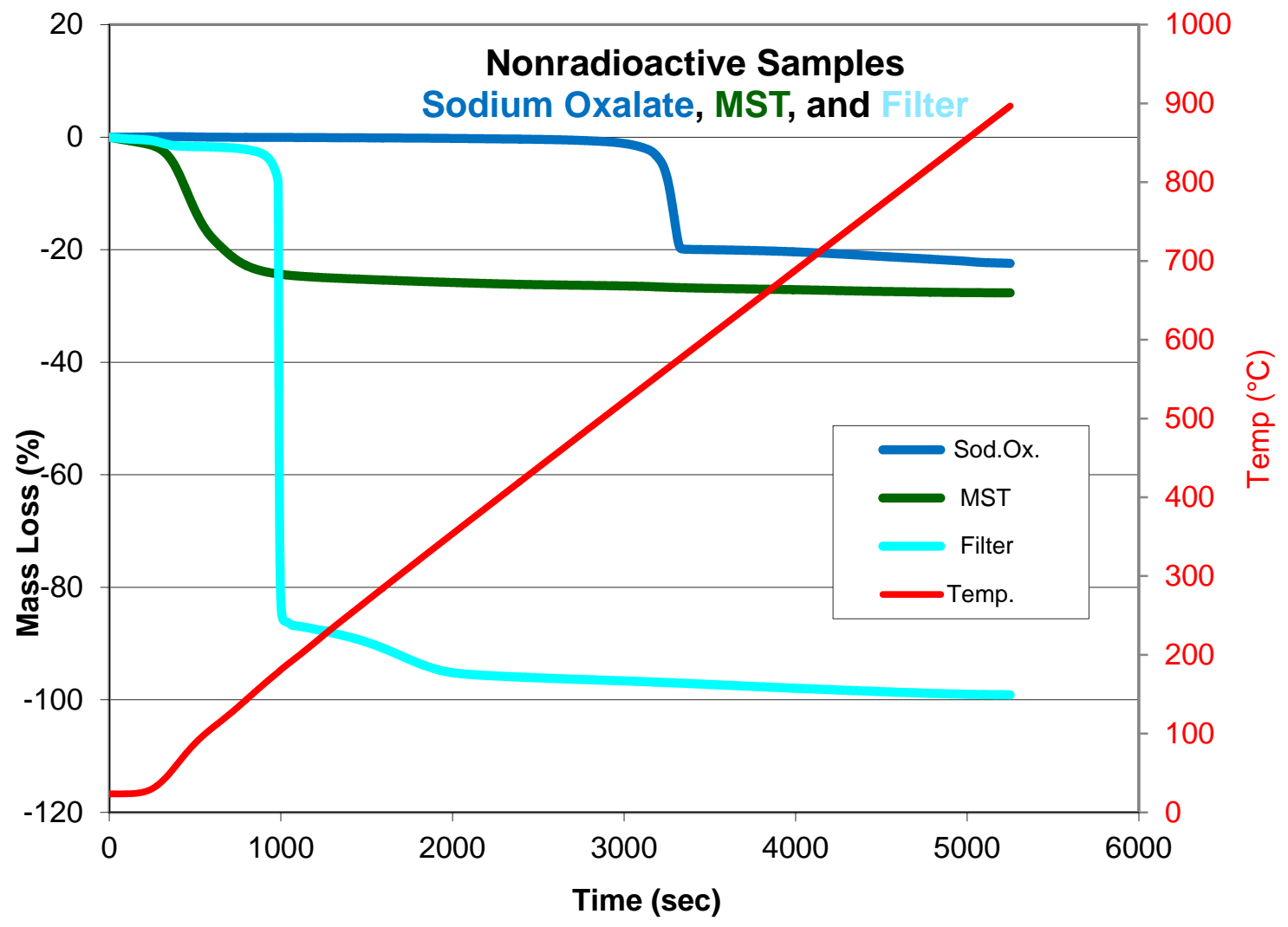

Figure 3-6. TGA Graph Showing Sodium Oxalate, MST and Cellulose Nitrate Filter Paper

Figure 3-7 presents the individual TGA traces from the radioactive washed PRFT solids (top) and the radioactive unwashed PRFT solids (bottom). The washed PRFT TGA trace appears similar to the MST powder showing a gradual mass loss at temperature up to $\sim 150{ }^{\circ} \mathrm{C}$ up to 1000 seconds, followed by only a slight positive slope through $900{ }^{\circ} \mathrm{C}$. The unwashed PRFT TGA trace shows a slightly steeper mass loss profile up to $\sim 100{ }^{\circ} \mathrm{C}$ and also shows a more gradual mass loss in the temperature range of 100 to $300{ }^{\circ} \mathrm{C}$. This latter feature is similar to the previous mass loss trace shown for the filter paper in the 100 to $300{ }^{\circ} \mathrm{C}$ range in Figure 3-6. Both washed and unwashed PRFT TGA traces show a gradual increase of a few mass percent loss after 1,000 seconds (washed) and after 2,000 seconds (unwashed). These slight trends are most likely attributed to the buoyancy of the TGA pan after loss of $>50$ mass percent of the original $5.9 \mathrm{mg}$ washed and $3.72 \mathrm{mg}$ unwashed PRFT samples. 


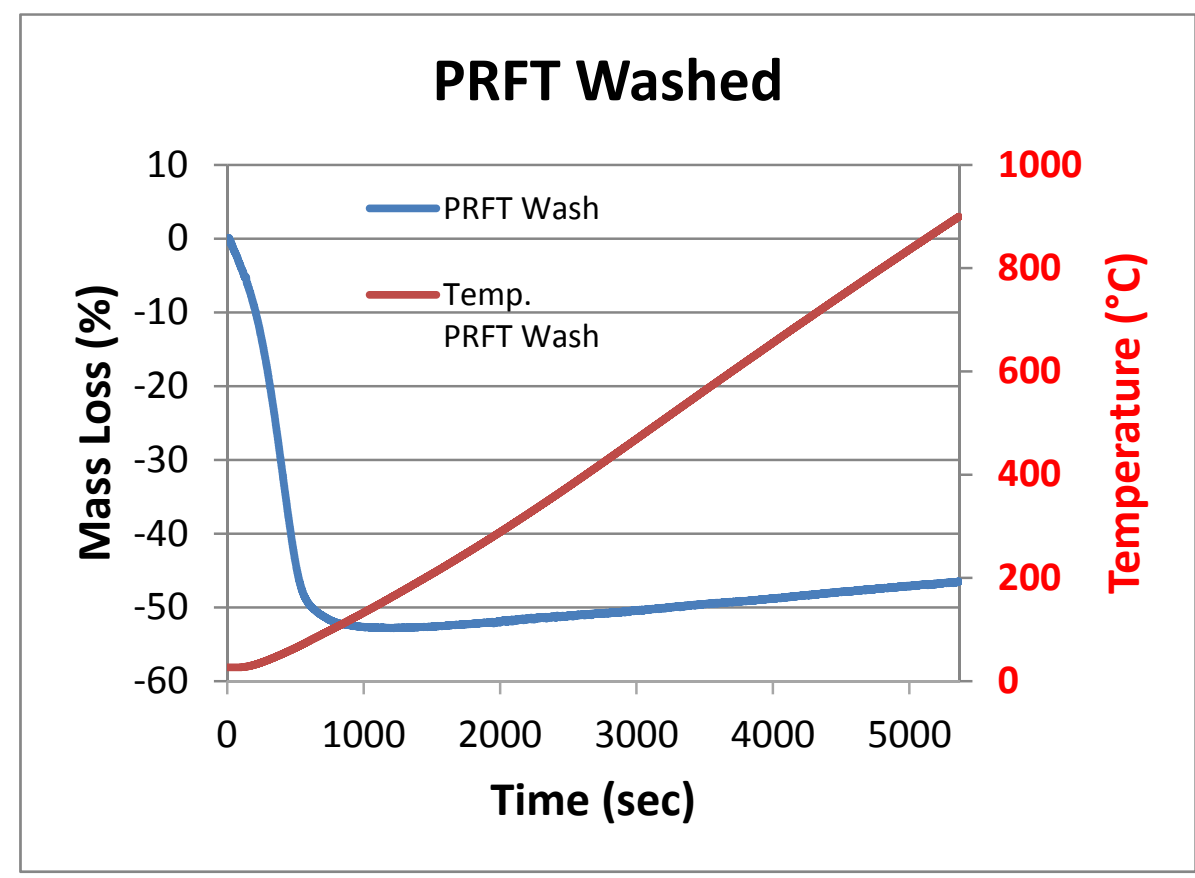

(a)

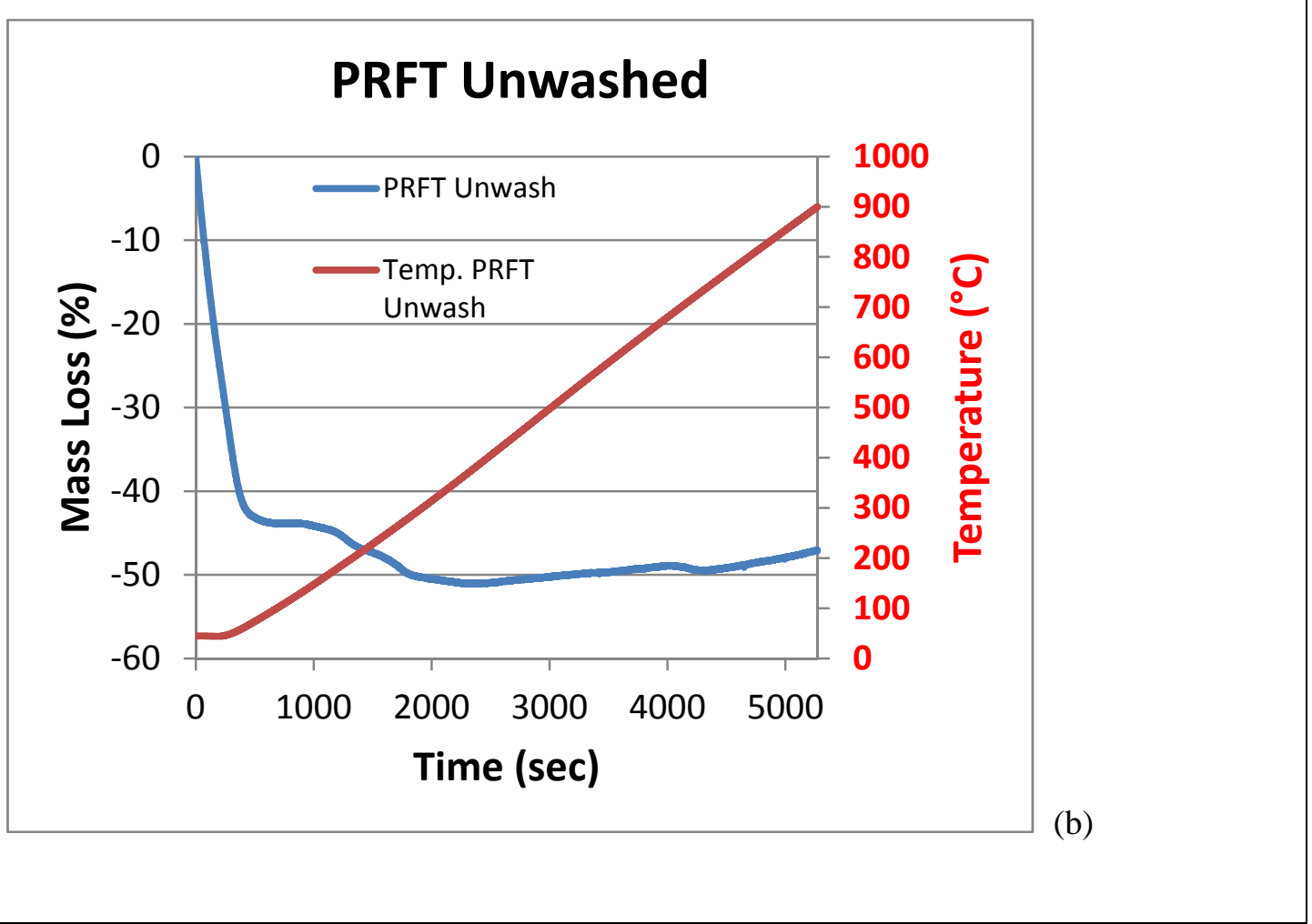

Figure 3-7. TGA Graph Showing (a) Washed Radioactive PRFT Solids and (b) Unwashed Radioactive PRFT Solids 
Both the washed and unwashed mass loss data for the PRFT samples are shown as overlays on the same graph in Figure 3-8 for ease of direct comparison. It should be noted that comparison of the radioactive sample TGA results to the nonradioactive MST and sodium oxalate TGA results suggests that no sodium oxalate is present in the radioactive solids, i.e., there is no mass loss feature of the PRFT samples at $\sim 570{ }^{\circ} \mathrm{C}$ as is seen in the pure sodium oxalate. These results are consistent with expectations that the sodium oxalate should be below its solubility limit based on the total sodium concentration of the PRFT slurry (see Ketusky, 2009 and Section 3.6 below).

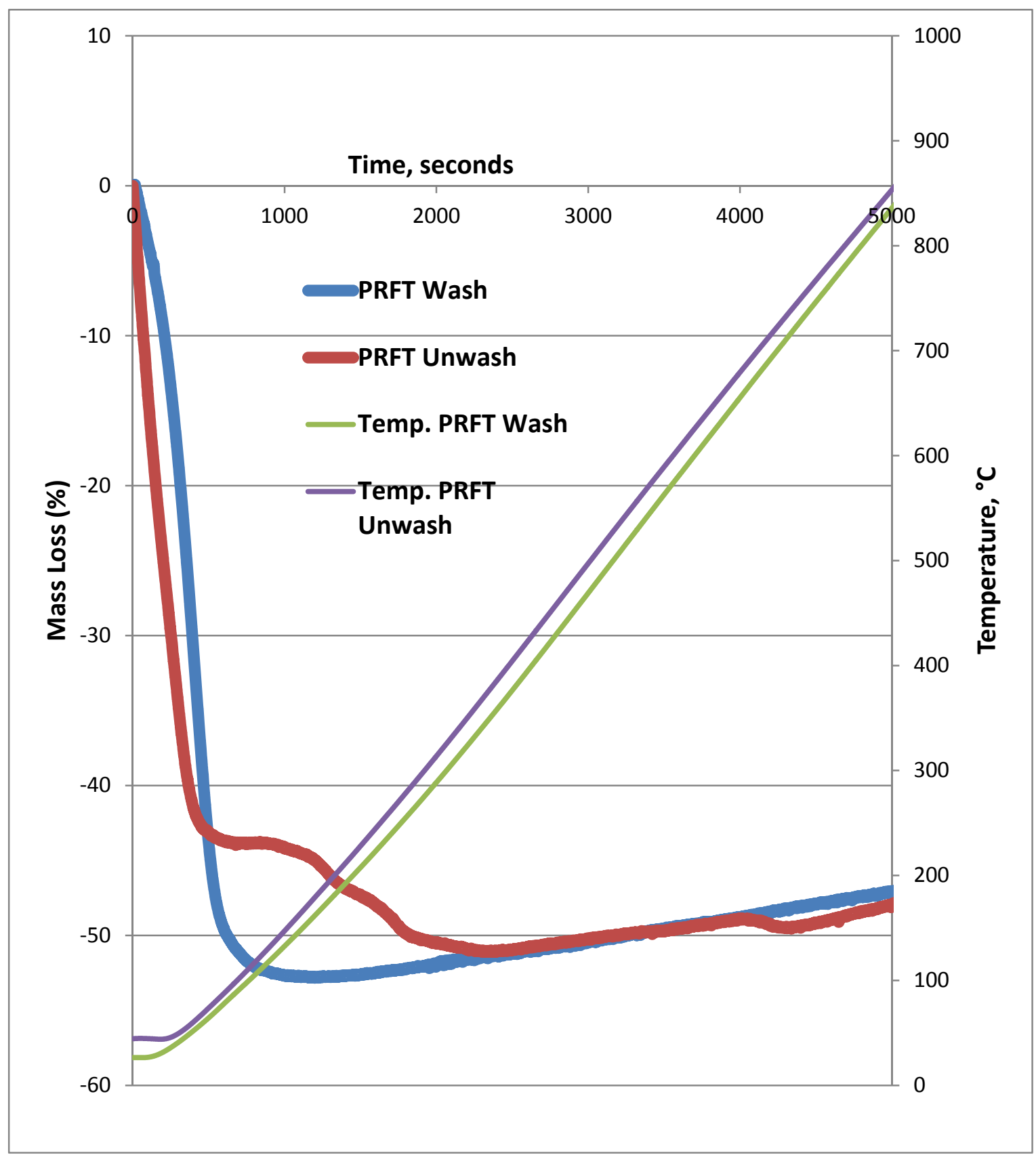

Figure 3-8. TGA Graph Showing Overlay of Washed and Unwashed Radioactive PRFT Solids 


\subsection{Filtrate Analysis, Carbon and Total Base Analysis}

The PRFT aqueous filtrate was analyzed by ICP-AES and IC as well as by carbon and base analyses. Wellmixed samples of the PRFT aqueous slurry were also submitted for carbon analysis. Results of the filtrate analyses are shown in Table 3-2 and carbon analysis for the filtrate and slurry are presented in Table 3-3. Table 3-4 gives the results of the filtrate base analyses. The metals and anion data in Table 3-2 indicate that the major filtrate species detected are $\mathrm{Al}, \mathrm{Na}$ and $\mathrm{S}$ (from molecular sulfate) from the ICP-AES and nitrate, nitrite, sulfate and oxalate from IC-anions. The soluble oxalate concentration of $0.05 \mathrm{M}$ is below the sodium oxalate solubility limit of $\sim 0.15 \mathrm{M} \mathrm{Na}_{2} \mathrm{C}_{2} \mathrm{O}_{4}$ in this $0.77 \mathrm{M}$ sodium solution (Ketusky, 2009). Trace soluble species include $\mathrm{B}, \mathrm{Cr}, \mathrm{Cu}, \mathrm{K}, \mathrm{Li}$ and $\mathrm{Si}$ from ICP-AES and Tc, Th and U from ICP-MS. No detectable Ti was present in the filtrate above the detection limit of $0.84 \mathrm{mg} / \mathrm{L}$. Trace anions phosphate, chloride and formate concentrations are all detectable and are below $50 \mathrm{mg} / \mathrm{L}$ from IC-anions.

Table 3-3 carbon analysis data shows that the filtrate carbon concentrations and speciation and the slurry carbon concentrations and speciation are the same to within analytical uncertainty. This indicates that no significant carbon species are associated with the slurry solids. The total inorganic carbon values of 354 $\mathrm{mg}$ carbon/L can be converted to a calculated carbonate $\left(\mathrm{CO}_{3}{ }^{2-}\right)$ concentration by multiplying by the carbonate formula weight / carbon weight, or 60/12 = 5, to give $5 \times 354 \mathrm{mg} / \mathrm{L} \mathrm{C}=1768 \mathrm{mg} / \mathrm{L}$ carbonate. The total organic carbon in the range of $1,273 \mathrm{mg}$ carbon/L to $1,280 \mathrm{mg}$ carbon/L can be attributed to the oxalate and trace levels of formate (previously shown in Table 3-2). Using formula weights for oxalate and formate, the IC-anion data can be converted to a carbon concentration for these two anions. The sum of oxalate carbon $(1,184 \mathrm{mg}$ carbon/L) and formate carbon $(11 \mathrm{mg}$ carbon/L) sum to $1,195 \mathrm{mg}$ carbon/L, which is $93-94 \%$ of the measured total organic carbon in the range of 1,273 to $1,280 \mathrm{mg}$ carbon/L. Table 3-4 base analysis of the PRFT filtrate indicates that the aqueous filtrate contains $0.366 \mathrm{M}$ total base, of which $84 \%$ is measured as free hydroxide at $0.308 \mathrm{M}$ or $5,230 \mathrm{mg} / \mathrm{L}$. 
Table 3-2. PRFT Filtrate Analysis [Number of Samples Included in Average]

\begin{tabular}{|c|c|c|c|}
\hline Element & $\begin{array}{l}\text { PRFT Supernate* } \\
\text { mg/L, (\%RSD**) }\end{array}$ & Element & $\begin{array}{l}\text { PRFT Supernate* } \\
\text { mg/L, }\left(\% \text { RSD }^{* *}\right)\end{array}$ \\
\hline $\mathrm{Ag}$ & $<0.270$ & $\mathrm{P}$ & $<15.6$ \\
\hline $\mathrm{Al}$ & $349(0.2)[3]$ & $\mathrm{Pb}$ & $<29.4$ \\
\hline B & $4.38(4.0)[3]$ & S & 265 (1.7) [3] \\
\hline $\mathrm{Ba}$ & $<0.140$ & $\mathrm{Sb}^{\ddagger}$ & $<0.0305$ \\
\hline $\mathrm{Be}$ & $<0.0200$ & $\mathrm{Si}$ & $6.31(2.2)[3]$ \\
\hline $\mathrm{Ca}$ & $<0.340$ & Sn & $<20.3$ \\
\hline $\mathrm{Cd}^{\ddagger}$ & $<0.0311$ & $\mathrm{Sr}$ & $<2.98$ \\
\hline $\mathrm{Ce}$ & $<2.260$ & $\mathrm{Tc}^{\ddagger}$ & $0.137(1.1)[3]$ \\
\hline Co & $<0.480$ & $\mathrm{Th}^{\ddagger}$ & 0.0113 (NA) [1] $* * * *$ \\
\hline $\mathrm{Cr}$ & $4.30(0.3)[3]$ & $\mathrm{Ti}$ & $<0.840$ \\
\hline $\mathrm{Cu}$ & $5.01(2.6)[3]$ & $\mathrm{U}^{\ddagger}$ & $0.663(0.9)[3]^{\ddagger \ddagger}$ \\
\hline $\mathrm{Fe}$ & $<0.520$ & V & $<0.140$ \\
\hline K & $38.4(7.2)[3]$ & $\mathrm{Zn}$ & $<0.400$ \\
\hline $\mathrm{La}$ & $<0.280$ & $\mathrm{Zr}$ & $<4.38$ \\
\hline $\mathrm{Li}$ & $4.19[3]$ & $\mathrm{NO}_{3}^{-}$ & $13700(1.1)[3]$ \\
\hline $\mathrm{Mg}$ & $<1.93$ & $\mathrm{NO}_{2}^{-}$ & 2290 (1.3) [3] \\
\hline $\mathrm{Mn}$ & $<0.180$ & $\mathrm{SO}_{4}{ }^{2-}$ & $614(2.5)$ [3] \\
\hline Mo & $<2.99$ & $\mathrm{PO}_{4}^{3-}$ & $37.3(1.5)[3]$ \\
\hline $\mathrm{Na}$ & $17800(0)[3] * * *$ & $\mathrm{Cl}^{-}$ & 15.3 (3.8) [3] \\
\hline \multirow[t]{2}{*}{$\mathrm{Ni}$} & $<2.39$ & $\mathrm{CHO}_{2}^{-}$ & $41.0(0)[3] * * *$ \\
\hline & & $\mathrm{C}_{2} \mathrm{O}_{4}^{2-}$ & $4340(2.2)[3]$ \\
\hline
\end{tabular}

* Ag through Zr, ICP-AES data except for Cd, Sb, Tc, Th and U by ICP-MS; Anions by IC;

** \%RSD values are relative to the true calculated averages of the quantities in the table, while the average values reported have been rounded off to a reasonable number of significant figures.

*** All replicate values identical for $\mathrm{Na}$; All replicate values identical for $\mathrm{CHO}_{2}$.

***** Only a single value from triplicate analyses detectable for Th.

$\ddagger \quad$ Calculated from MS data for Cd: Cd-111, Cd-112, Cd-114; Sb: Sb-121 and Sb-123; Tc: Tc-99 and Th: Th-232.

\# Calculated from the sum of MS data for U: U-235and U-238. Only two detectable values for U-235. No detectable uranium isotopes for U-233, U-234 or U-236. 
Table 3-3. Carbon Analysis for PRFT Filtrate and Slurry [Number of Samples Included in Average]

\begin{tabular}{lcc}
\hline Analyte & $\begin{array}{c}\text { PRFT Filtrate } \\
\text { mg C/L filtrate, } \\
\text { (\%RSD*) }\end{array}$ & $\begin{array}{c}\text { PRFT Slurry } \\
\text { mg C/L slurry, } \\
\text { (\%RSD*) }\end{array}$ \\
\hline Total Inorganic Carbon & $354(0.2)[3]$ & $354(0.8)[2]$ \\
Total Organic Carbon & $1280(0)^{* *}[3]$ & $1270(0.5)[3]$ \\
& $1630(0.4)[3]$ & $1630(0.6)[3]$ \\
\hline Total Carbon & $\begin{array}{l}\text { \%RSD values are relative to the true calculated averages of the quantities in the table, while the } \\
\text { average values reported have been rounded off to a reasonable number of significant figures. }\end{array}$ \\
** Replicate values for Total Organic Carbon were identical.
\end{tabular}

Table 3-4. Base Analysis for PRFT Filtrate [Number of Samples Included in Average]

\begin{tabular}{cc}
\hline Analyte & $\begin{array}{c}\text { PRFT Filtrate } \\
\text { mol/L, (\%RSD*) }\end{array}$ \\
\hline Total Base & $0.366(0.8)[3]$ \\
Free OH & $0.308(1.5)[3]$ \\
Other Base & 0.047 (6.5) [3] \\
\hline * \%RSD values are relative to the true calculated averages of the \\
$\begin{array}{l}\text { quantities in the table, while the average values reported have been } \\
\text { rounded off to a reasonable number of significant figures. }\end{array}$
\end{tabular}

\subsection{Mixed Acid Dissolution Analysis}

Table 3-5 includes the elemental results derived from analysis of the mixed acid dissolved PRFT slurry. These data indicate the major elemental species are $\mathrm{Na}$ and $\mathrm{Ti}$ at 30 and $5.8 \mathrm{Wt} \%$ total dried solids, respectively, with $\mathrm{Al}, \mathrm{S}$ (from sulfate), Si and U above $0.1 \mathrm{Wt} . \%$ total dried solids. Trace levels of detectable Fe and Si were observed in the acid dissolution blank so the reported values in Table 3-5 for Fe and Si have been blank-corrected. Many of the insoluble species not detected in the filtrate from Table 3-2 ( $\mathrm{Ba}, \mathrm{Be}, \mathrm{Ca}, \mathrm{Cd}, \mathrm{Co}, \mathrm{Fe}, \mathrm{Pb}, \mathrm{V}$ and $\mathrm{Zn}$ ) were detected in very low levels in the dissolved PRFT slurry shown in Table 3-5. Notably Ti is undetectable in the filtrate but present at $5.8 \mathrm{Wt} . \%$ total dried solids in the dissolved slurry. The analyzed value for $\mathrm{S}$ from the PRFT slurry of $0.437 \mathrm{Wt} \% \mathrm{TS}$ with good precision (\%RSD of 1.9) is a critical element for consideration of how much PRFT slurry can be added to the SRAT in processing due to the sulfate limitation in glass (Brown, 2014). Examination of Table 3-5 with respect to major elements associated with caustic HLW sludge (Ketusky 2009, Bannochie, 2013a) such as Ca, Fe, Hg, $\mathrm{Mn}, \mathrm{Ni}$ and $\mathrm{U}$ also indicates that in agreement with visual observations of the PRFT slurry, there does not appear to be any significant HLW sludge components present. The concentrations of Ca, Fe, $\mathrm{Hg}$ and $\mathrm{U}$ are all low (at or below $0.11 \mathrm{wt} \%$ ) and there is no detectable Mn or Ni present. The lack of HLW sludge solid 
components is expected and has been noted by the Salt IPT chemistry team citing that "the mixing pump has been removed from Tank 49H, the feed tank to ARP-MCU, so the insoluble solids settle out” (Wilmarth, 2013).

It was noticed that the Al Wt.\% total dried solids reported in Table 3-5 is low compared to that expected from soluble $\mathrm{Al}$ in the filtrate. The soluble $\mathrm{Al}$ in the filtrate of $349 \mathrm{mg} / \mathrm{L}$ is calculated to be $0.56 \mathrm{Wt} . \%$ total dried solids vs. the observed value of only $0.17 \pm 0.05 \mathrm{Wt}$.\% total dried solids. This apparent anomaly can be explained by the presence of trace white solids that were noticed in the mixed acid dissolved PRFT slurries when they were inspected after all the dissolution data had been reported. Previous work involving different dissolution methods on $\mathrm{Al}$-containing sludge samples indicates that a mixed nitric/hydrofluoric acid method can give low biased Al data when compared to more aggressive fusion methods (Click, 2011). Various solids observed in the mixed acid cold chemical method such as boehmite ( $\mathrm{AlO}(\mathrm{OH}))$ ) and numerous mixed $\mathrm{Al} / \mathrm{F}$ solids are cited in that work.

The mixed acid digestion of the PRFT slurry was mainly targeted at complete dissolution of the Ti from the MST. Complete dissolution of the MST can be confirmed by a calculation to estimate how much Ti should be in solution assuming the measured $0.61 \mathrm{wt} \%$ insoluble solids is pure MST with the empirical formula of $\mathrm{NaTi}_{2} \mathrm{O}_{5} \mathrm{H}$. One gram of slurry should then contain $6.1 \mathrm{mg}$ of MST, or $2.9 \mathrm{mg}$ of Ti which would give a concentration of Ti of 2,925 $\mu \mathrm{g} / \mathrm{g}$. The analyzed value for Ti is about $15 \%$ higher at 3,480 $\pm 174 \mu \mathrm{g} / \mathrm{g}$. 
Table 3-5. Elemental and Anion Concentrations in PRFT Slurry in Wt. \% Total Dried Solids [Number of Samples Included in Average]

\begin{tabular}{cccc}
\hline Element & $\begin{array}{c}\text { PRFT Slurry } \\
\text { Wt\% TS (\%RSD**) }\end{array}$ & Element & $\begin{array}{c}\text { PRFT Slurry } \\
\text { Wt\% TS (\% RSD**) }\end{array}$ \\
\hline $\mathrm{Ag}$ & $<8.14 \mathrm{E}-04$ & $\mathrm{Mo}$ & $<9.01 \mathrm{E}-03$ \\
$\mathrm{Al}$ & $1.69 \mathrm{E}-01(31)[3]$ & $\mathrm{Na}$ & $2.99 \mathrm{E}+01(4.9)[3]$ \\
$\mathrm{As}^{*}$ & $<3.32 \mathrm{E}-04$ & $\mathrm{Ni}$ & $<7.20 \mathrm{E}-03$ \\
$\mathrm{~B}$ & $2.20 \mathrm{E}-02(19)[3]$ & $\mathrm{P}$ & $<1.10 \mathrm{E}-02$ \\
$\mathrm{Ba}$ & $2.68 \mathrm{E}-03(6.1)[3]$ & $\mathrm{Pb}^{\ddagger}$ & $1.54 \mathrm{E}-07(8.9)[3]$ \\
$\mathrm{Be}$ & $3.03 \mathrm{E}-04(5.6)[3]$ & $\mathrm{S}$ & $4.37 \mathrm{E}-01(1.9)[3]$ \\
$\mathrm{Ca}$ & $3.35 \mathrm{E}-02(9.3)[3]$ & $\mathrm{Sb}^{\ddagger}$ & $<1.58 \mathrm{E}-04$ \\
$\mathrm{Cd}{ }^{\ddagger}$ & $2.33 \mathrm{E}-06(4.7)[3]$ & $\mathrm{Se} \mathrm{C}^{*}$ & $<6.64 \mathrm{E}-04$ \\
$\mathrm{Co}$ & $3.13 \mathrm{E}-03(5.6)[3]$ & $\mathrm{Si}$ & $4.74 \mathrm{E}-01(18)[3]$ \\
$\mathrm{Cr}$ & $8.55 \mathrm{E}-03(1.2)[3]$ & $\mathrm{Sn}$ & $<6.12 \mathrm{E}-02$ \\
$\mathrm{Cu}$ & $2.60 \mathrm{E}-02(4.6)[3]$ & $\mathrm{Sr}$ & $<8.99 \mathrm{E}-03$ \\
$\mathrm{Fe}$ & $7.01 \mathrm{E}-02(4.6)[3]$ & $\mathrm{Tc}$ & $1.96 \mathrm{E}-04(7.3)[3]$ \\
$\mathrm{Hg}{ }^{\ddagger}$ & $3.59 \mathrm{E}-02(5.3)[3]$ & $\mathrm{Th}$ & $<1.21 \mathrm{E}-04$ \\
$\mathrm{~K}$ & $6.09 \mathrm{E}-02(2.7)[3]$ & $\mathrm{Ti}$ & $5.84 \mathrm{E}+00(5.0)[3]$ \\
$\mathrm{La}$ & $<9.05 \mathrm{E}-05$ & $\mathrm{U}^{\ddagger}$ & $1.07 \mathrm{E}-01(3.3)[3]$ \\
$\mathrm{Li}$ & $2.65 \mathrm{E}-02(10).[3]$ & $\mathrm{V}$ & $2.95 \mathrm{E}-03(5.2)[3]$ \\
$\mathrm{Mg}$ & $<5.81 \mathrm{E}-03$ & $\mathrm{Zn}$ & $7.64 \mathrm{E}-03(4.9)[3]$ \\
$\mathrm{Mn}$ & $<7.56 \mathrm{E}-04$ & $\mathrm{Zr}$ & $<5.30 \mathrm{E}-04$ \\
\hline
\end{tabular}

\footnotetext{
Ag through Zr, ICP-AES data except for As, Se, Hg from AA-methods and Cd, Pb, Sb, Tc, Th and U from ICP-MS, all from slurry dissolution; Anions by IC of supernate, converted to wt\% TS using slurry density.

** Parenthetical \%RSD values are relative to the true calculated averages of the quantities in the table, while the average values reported have been rounded off to a reasonable number of significant figures.

‡ Calculated from MS data for Cd: Cd-111, Cd-112, Cd-114; Pb: Pb-206, Pb-207, Pb-208; Sb: Sb-121 and Sb-123; Tc: Tc-99 and Th: Th-232.

\# Calculated from the sum of MS data for U: U-233, U-234, U-235, U-236, and U-238.
} 


\subsection{Comparison of SRNL Analyses to DWPF Analyses}

Results from DWPF PRFT samples are shown in Table 3-6 for comparison to the SRNL sample analyses from previous tables. The DWPF sample results spanned four years from August 2009 through August 2013 and were transmitted to SRNL from DWPF in the form of an informal or undocumented spreadsheet (Mahannah, 2013). These data are retained in SRNL E Notebook, "Examination of PRFT MST Sample", Experiment L2320-00016-13 (Bannochie, 2013b). SRNL sample analyses are shown in the first data column, the DWPF sample from June 3, 2013 data are shown in the second data column and the other data columns show overall DWPF average, standard deviation and \% relative standard deviation of some 30 samples from 2009 to 2013. The DWPF calcined solids method uses covered platinum crucibles and heats samples up stepwise through $265^{\circ} \mathrm{C}$ for $1 \mathrm{hr}$ and $650{ }^{\circ} \mathrm{C}$ for one hour, followed by a final target temperature of $1050{ }^{\circ} \mathrm{C}$ for $1 \mathrm{hr}$ (DWPF SW4-15.201, Weight Percent Solids, Section 2.3). The SRNL procedure typically uses open aluminum crucibles with a direct heat up at nominally $10{ }^{\circ} \mathrm{C} / \mathrm{min}$ to a target of $1100{ }^{\circ} \mathrm{C}$ for at least 2 hrs (Bannochie, 2012).

The DWPF total oxalate method derives from past experience with insoluble oxalates in sludge (Coleman, 2002b). This total oxalate method involves step-wise addition of $3 \mathrm{~mL}$ of $\mathrm{HCl}$ and $3 \mathrm{~mL}$ of $\mathrm{HNO}_{3}$ to dissolve a $1 \mathrm{~g}$ PRFT slurry sample before IC analysis. Oxalate and the other anions shown in Table 3-6 were analyzed by IC. Elemental values reported for $\mathrm{Al}, \mathrm{Na}$ and $\mathrm{Ti}$ in the DWPF data were determined using a Cold Chemical (CC) dissolution method that involves adding equal volumes of first concentrated HF followed by stirring and then addition of the concentrated nitric acid with stirring. No elevated temperatures or boric acid for fluoride complexation are used (DWPF SW4-15.201, Cold Chem. Method, Section 2.1).

The Wt.\% total solids and density data from the SRNL sample and the DWPF sample are in good agreement. The SRNL sample shows somewhat lower calcined solids (2.82 Wt.\%) vs. the DWPF single sample and the 4-year average of $3.72 \mathrm{Wt} . \%$ and $4.37 \mathrm{Wt} . \%$, respectively. These differences could be due to the subtle differences in the calcined solids methods used in the two facilities.

Nitrate, nitrite and oxalate values from IC-anions are similar for the DWPF and SRNL results and the SRNL sulfate value is only $84 \%$ of the DWPF $6 / 3 / 13$ value but is $91 \%$ of the average 4 -year value. Both the Na and Ti values agree between the DWPF (33.14 and 5.83 Wt.\% total dried solids) and SRNL (29.9 and 5.8 Wt.\% total dried solids) analyses.

The measured Al value from SRNL dissolution is biased low as previously discussed above. The calculated total $\mathrm{Al}$ of $0.56 \mathrm{Wt}$.\% total dried solids from filtrate analyses is only half of the DWPF 6/3/13 value of $1.17 \mathrm{Wt} \%$ total dried solids. However the DWPF Al data shows the highest variability of elements measured with a \%RSD for the overall average of 48\%. The SRNL calculated Al value of 0.56 Wt.\% total dried solids (from filtrate only) is in the range of the overall DWPF cold chemical dissolution average of $0.77 \pm 0.37 \mathrm{Wt}$.\% total dried solids.

DWPF also reports a 'Total oxalate' value for comparison to the supernate oxalate in Table 3-6. For the June 13, 2013 sample the total oxalate is actually only 93\% of the soluble oxalate. However for the 4-year average these two average values are essentially the same to within the variability shown of 11 to $12 \%$ RSD. The similarity of the overall averages for the oxalate and total oxalate DWPF data suggest that insignificant amounts of oxalate are insoluble in the PRFT slurry. The same conclusion regarding the lack of any appreciable carbon species in the PRFT solids was discussed earlier from the SRNL carbon measurements on both filtrate and PRFT slurry. 
SRNL-STI-2013-00735

Revision 0

Table 3-6. PRFT Sample Analyses from SRNL and DWPF

\begin{tabular}{|c|c|c|c|c|c|}
\hline Property or Species & SRNL & $\begin{array}{c}\text { DWPF } \\
\text { June 3, } 2013 \\
\end{array}$ & $\begin{array}{l}\text { DWPF } \\
\text { Avg.* }\end{array}$ & $\begin{array}{c}\text { DWPF } \\
\text { St. Dev. * }\end{array}$ & $\begin{array}{l}\text { DWPF } \\
\text { \%RSD* }\end{array}$ \\
\hline Wt. \% dried Avg. & 5.96 & 5.54 & 5.97 & 1.07 & 18 \\
\hline Wt. \% calcined Avg. & 2.82 & 3.72 & 4.37 & 0.96 & 22 \\
\hline Density, g/mL & 1.049 & 1.05 & 1.06 & 0.08 & 7 \\
\hline Nitrite, mg/L & 2290 & 2423 & 2036 & 685 & 34 \\
\hline Nitrate, mg/L & 13700 & 14014 & 11477 & 2507 & 22 \\
\hline Sulfate, mg/L & 614 & 733 & 674 & 140 & 21 \\
\hline Oxalate, mg/L & 4340 & 4818 & 4576 & 528 & 12 \\
\hline Total Oxalate Avg., mg/L & $\mathrm{NA}^{* *}$ & 4485 & 4789 & 547 & 11 \\
\hline Al, Wt.\% Total dried solids & $0.17 * * *$ & 1.17 & 0.77 & 0.37 & 48 \\
\hline Na, Wt.\% Total dried solids & 29.9 & 33.1 & 34.5 & 4.83 & 14 \\
\hline Ti, Wt.\% Total dried solids & 5.80 & 5.83 & 9.18 & 3.40 & 37 \\
\hline
\end{tabular}

\subsection{Conclusions}

The overall conclusions from analyses performed in this study are that the PRFT slurry consists of 0.61 Wt.\% insoluble MST solids suspended in a $0.77 \mathrm{M}\left[\mathrm{Na}^{+}\right]$caustic solution containing various anions such as nitrate, nitrite, sulfate, carbonate and oxalate. The corresponding measured sulfur level in the PRFT slurry, a critical element for determining how much of the PRFT slurry gets blended into the SRAT, is 0.437 Wt.\% TS. The PRFT slurry does not contain insoluble oxalates nor significant quantities of high activity sludge solids. The following detailed findings and conclusions were drawn from the analytical results reported in this study:

The PRFT aqueous slurry from DWPF was found to contain $5.96 \mathrm{Wt} \%$ total dried solids. Of these total dried solids, relatively low levels of insoluble solids $(0.61 \mathrm{Wt} . \%)$ were measured. The densities of both the filtrate and slurry were $1.05 \mathrm{~g} / \mathrm{mL}$.

Particle size distribution of the PRFT solids in filtered caustic simulant and XRD analysis of washed/dried PRFT solids indicate that the PRFT slurry contains a bimodal distribution of particles in the range of 1 and $6 \mu \mathrm{m}$ and that the particles contain sodium titanium oxide hydroxide $\mathrm{Na}_{2} \mathrm{Ti}_{2} \mathrm{O}_{4}(\mathrm{OH})_{2}$ crystalline material as determined by XRD. These data are in excellent agreement with similar data obtained from laboratory sampling of vendor supplied MST. SEM combined with EDS analysis of washed/dried PRFT solids shows the particles to be like previous MST analyses consisting of irregular shaped micron-sized solids consisting primarily of $\mathrm{Na}$ and $\mathrm{Ti}$.

Thermogravimetric analysis of the washed and unwashed PRFT solids shows that the washed solids are very similar to MST solids. The TGA mass loss signal for the unwashed solids shows similar features to TGA performed on cellulose nitrate filter paper indicating significant presence of the deteriorated filter in this unwashed sample. Neither the washed nor unwashed PRFT solids TGA traces showed any features that would indicate presence of sodium oxalate solids. 
The PRFT filtrate analysis shows that $\mathrm{Na}, \mathrm{S}$ and $\mathrm{Al}$ are major soluble species with trace levels of $\mathrm{B}, \mathrm{Cr}, \mathrm{Cu}$, $\mathrm{K}, \mathrm{Li}, \mathrm{Si}, \mathrm{Tc}$, Th and U present. Nitrate, nitrite, sulfate, oxalate, carbonate and hydroxide are major soluble anion species. There is good agreement between the analyzed TOC and the sum of oxalate and the minor species formate.

Comparison of the amount and speciation of the carbon species between filtrate and slurry indicates no significant carbon-containing species, e.g., sodium oxalate, are present in the slurry solids.

Dissolution of the PRFT slurry and subsequent analysis shows that $\mathrm{Na}, \mathrm{Ti}, \mathrm{Si}$ and $\mathrm{U}$ are the major elements present on a wt\% TS basis with 30, 5.8, 0.47 and $0.11 \mathrm{Wt}$.\% total dried solids, respectively. The amount of $\mathrm{Al}$ in the dissolved PRFT slurry is less than that calculated from the PRFT filtrate alone which suggests that the mixed acid digestion used in this work is not optimized for $\mathrm{Al}$ recovery. The concentrations of Ca, Fe, $\mathrm{Hg}$ and $\mathrm{U}$ are all low (at or below $0.11 \mathrm{wt} \%$ ) and there is no detectable $\mathrm{Mn}$ or Ni present which indicates no significant HLW sludge solids are present in the PRFT slurry sample. 
SRNL-STI-2013-00735

Revision 0

\subsection{References}

Bannochie, C. J., Shielded Cells Operation Supernate and Slurry Density Determination Procedure, Manual L29, Procedure ITS-0118, Rev. 2; Savannah River National Laboratory, Aiken, SC 29808 (2012).

Bannochie, C.J., Tank 40 Final Sludge Batch 8 Chemical Characterization Results, SRNL-STI-2013-00504, Rev. 0; Savannah River Site, Aiken, SC 29808 (2013a).

Bannochie, C. J. “Examination of PRFT MST Sample”, Experiment L2320-00016-13, SRNL E Notebook (Production); Savannah River National Laboratory, Aiken, SC 29808 (2013b).

Bricker, J. M., Technical Task Request, S-TTR-S-00001, Rev. 0; Savannah River Site, Aiken, SC 29808 (2013).

Brown, W.E., Savannah River Remediations Engineering Weekly Report, email correspondence, 1/17/2014 (2014).

Click, D. R., Edwards, T. B., Jones, M. A. and Wiedenman, B. J., Verification of the Defense Waste Processing Facility's (DWPF) Process Digestion Method for the Sludge Batch 7A Qualification Sample, SRNL-STI-2011-00158, Rev. 0; Savannah River National Laboratory, Aiken, SC, 29808 (2011).

Coleman, C. J., Evaluation of the DWPF Cold Chem Dissolution Method with Sludge Batch 3 Simulant, WSRC-TR-2002-00496, Westinghouse Savannah River Co., Aiken, SC, 29808 (2002a).

Coleman, C. J., Method to Determine Oxalate in High-Level Sludge by Ion Chromatography, WSRC-TR2002-00497, Westinghouse Savannah River Co., Aiken, SC, 29808 (2002b).

Crawford, C. L. and Bannochie, C. J., Initial Characterization of the PRFT Sample from DWPF, SRNLL3100-2013-00144, Rev. 1; Savannah River National Laboratory, Aiken, SC 29808 (2013).

DWPF Analytical Cells System Operating Manual, SW4-15.201, Weight Percent Analysis, Section 2.3, Revision 11, Savannah River Site, Aiken, SC 29808 (2013).

DWPF Analytical Cells System Operating Manual, SW4-15.201, Cold Chem Preparation, Section 2.1, Revision 8, Savannah River Site, Aiken, SC 29808 (2011).

Fellinger, T. L., Facility Upgrades for Receipt from Actinide Removal and Modular Caustic Side Solvent Extraction Processes at the Savannah River Site, Waste Management 2007 Conference, February 25 March 1, 2007, Tucson, AZ; http://www.wmsym.org/archives/2007/pdfs/7383.pdf (2007).

Handfinger, H., et al., DWPF Production and Reliability Review, Final Report, SRR-LWP-2013-00021; Savannah River Site, Aiken, SC 29808 (2013).

Hobbs, D. T., Barnes, M. J., Pulmano, R. L., Marshall , K. M., Edwards , T. B., Bronikowski, M. G. \& Fink, S. D., Strontium and Actinide Separations from High Level Nuclear Waste Solutions Using Monosodium Titanate 1. Simulant Testing, Separation Science and Technology, 40:15, 3093-3111 (2005). 
Hobbs, D. T., Properties and Uses of Sodium Titanates and Peroxotitanate, Journal of the South Carolina Academy of Science, 9(1), 20-24 (2011).

Ketusky, E.T., Enhanced Chemical Cleaning, U.S. Department of Energy Office of Waste Processing Technical Exchange. (http://srnl.doe.gov/owp_techex09/denver_webcast/slides/07-1_Ketusky.pdf) (2009).

Lambert, D. P., Martino, C. J., Bannochie, C. J., Plan for DWPF Chemical Process Cell Actual Waste Processability Testing, SRNL-RP-2013-00340, Rev. 0; Savannah River National Laboratory, Aiken, SC 29808 (2013).

Mahannah, R. N., DWPF PRFT Sample Results Spreadsheet, e-mail correspondence from R. N. Mahannah to D. R. Click, Savannah River Site, Aiken, SC 29808 (2013).

Pareizs, J. M., Weight Percent Solids Determination Using a Furnace or Oven, Manual L29, Procedure ITS-0078, Rev. 1; Savannah River National Laboratory, Aiken, SC 29808 (2012).

Reynolds, J. G., Application of Mixture Models to Solubility Calculations, Using Sodium Oxalate as an Example, Separation Science and Technology, 43: 2872-2886, 2008.

Specification for Procurement of 15 wt\% Monosodium Titanate (MST) for 96-H ARP (U), Savannah River Site Spec. No. X-SPP-H-00012, Rev. 6, Savannah River Site, Aiken, SC 29808 (2010).

Taylor-Pashow, K.M. “Sr/Actinide Research Book 17”, SRNL-NB-2012-00040, Savannah River National Laboratory, Aiken, SC 29808 (2012).

Wilmarth, W. R., et al., Salt Integrated Project Chemistry Team Report, SRNL-STI-2013-00354, SRR-STI2013-00375, Rev. 0; Savannah River National Laboratory, Aiken, SC 29808 (2013). 
SRNL-STI-2013-00735

Revision 0

Appendix A. Microscopy Data 


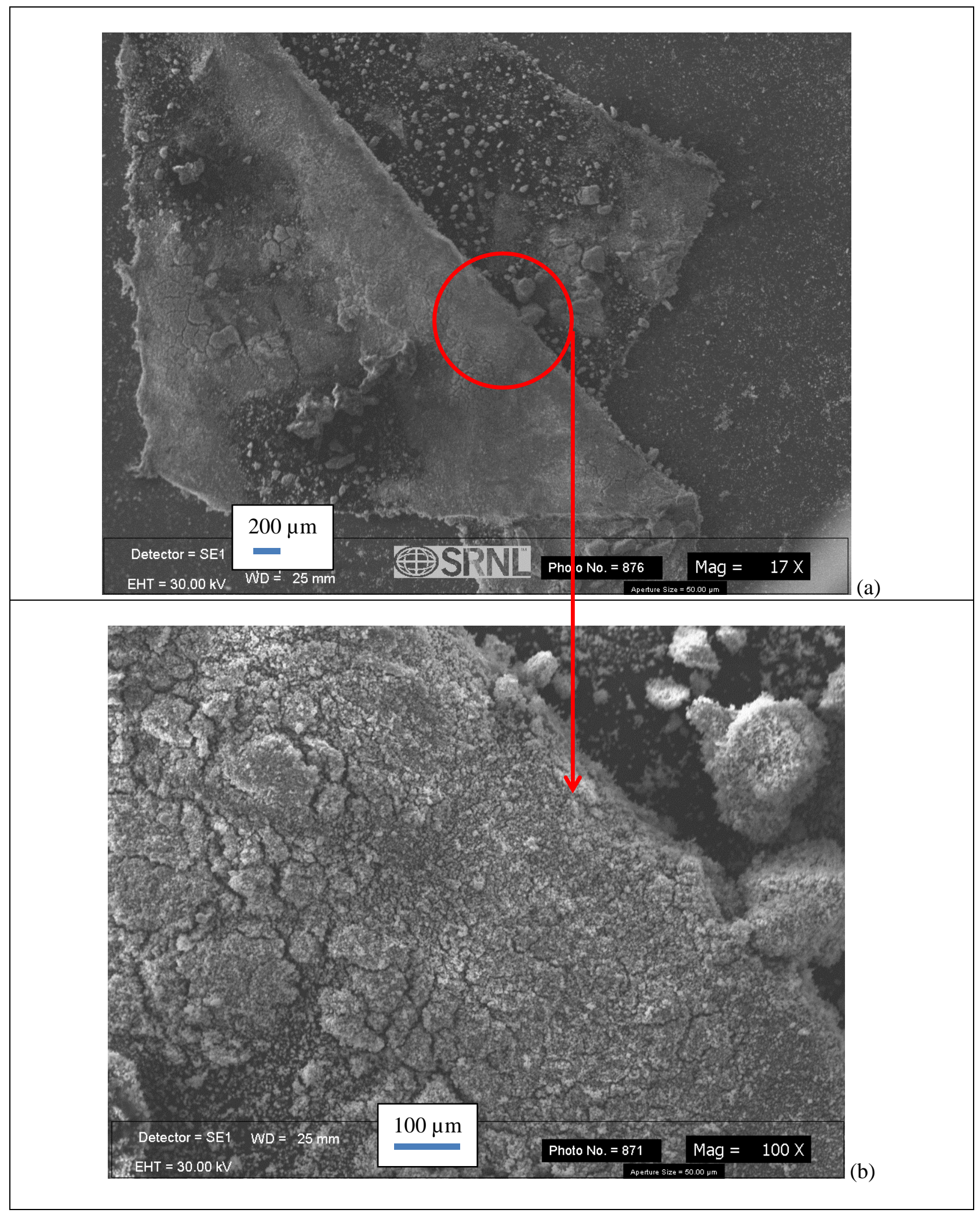

Figure A- 1. SEM Images of PRFT Sample 1 Material at (a) 17X Magnification showing 200 $\mathrm{mm}$ scale bar and (b) 100X Magnification showing 100 um scale bar. 


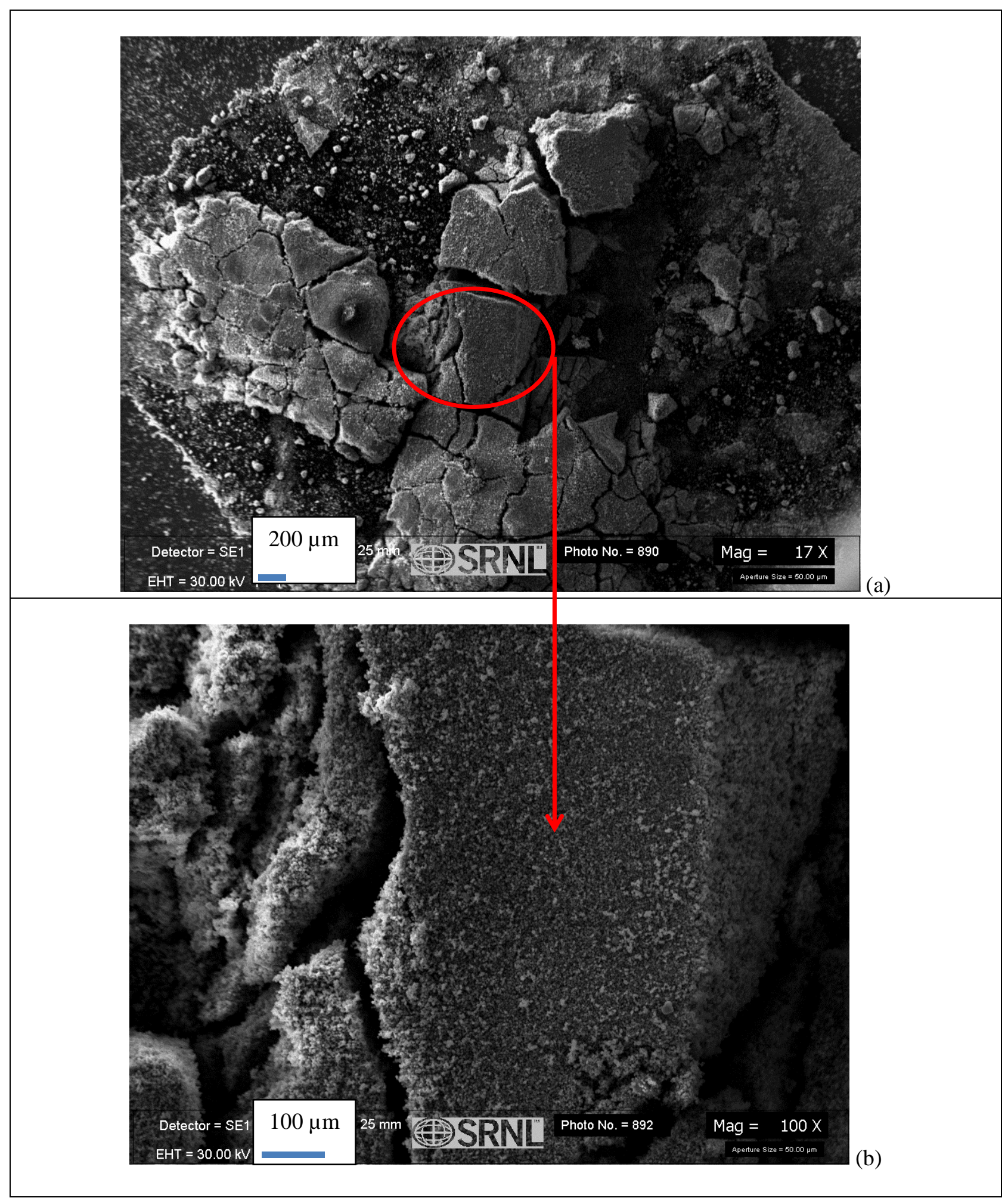

Figure A- 2. SEM Images of PRFT Sample 2 Material at (a) 17X Magnification showing $200 \mu \mathrm{m}$ scale bar and (b) 100X Magnification showing $100 \mu \mathrm{m}$ scale bar. 
SRNL-STI-2013-00735

Revision 0

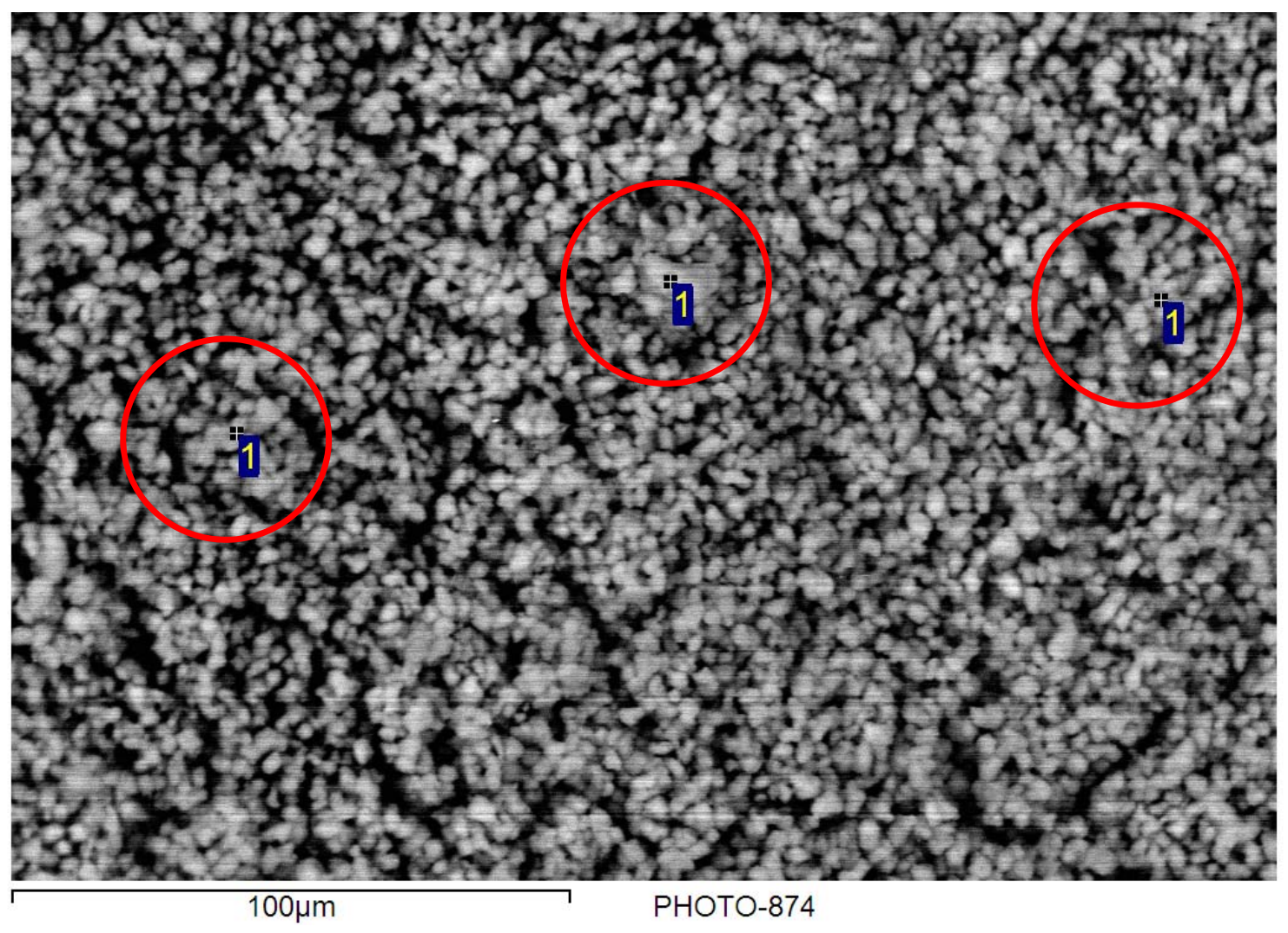

Figure A- 3. A 500X magnification SEM of PRFT sample 1 material showing $100 \mu \mathrm{m}$ scale bar. Regions labeled with a ' 1 ' inside the red circles were analyzed by EDS. 


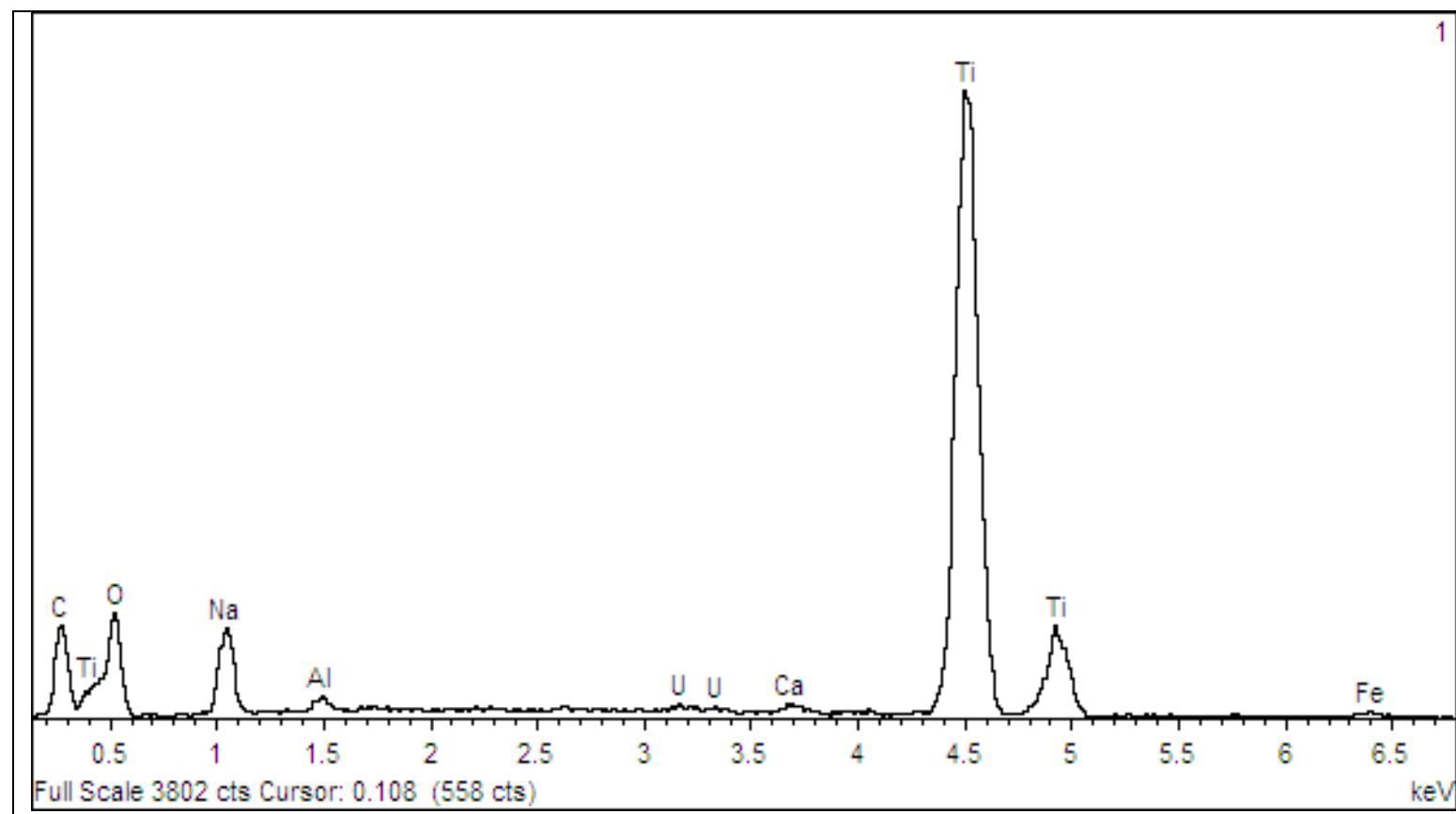

(a)

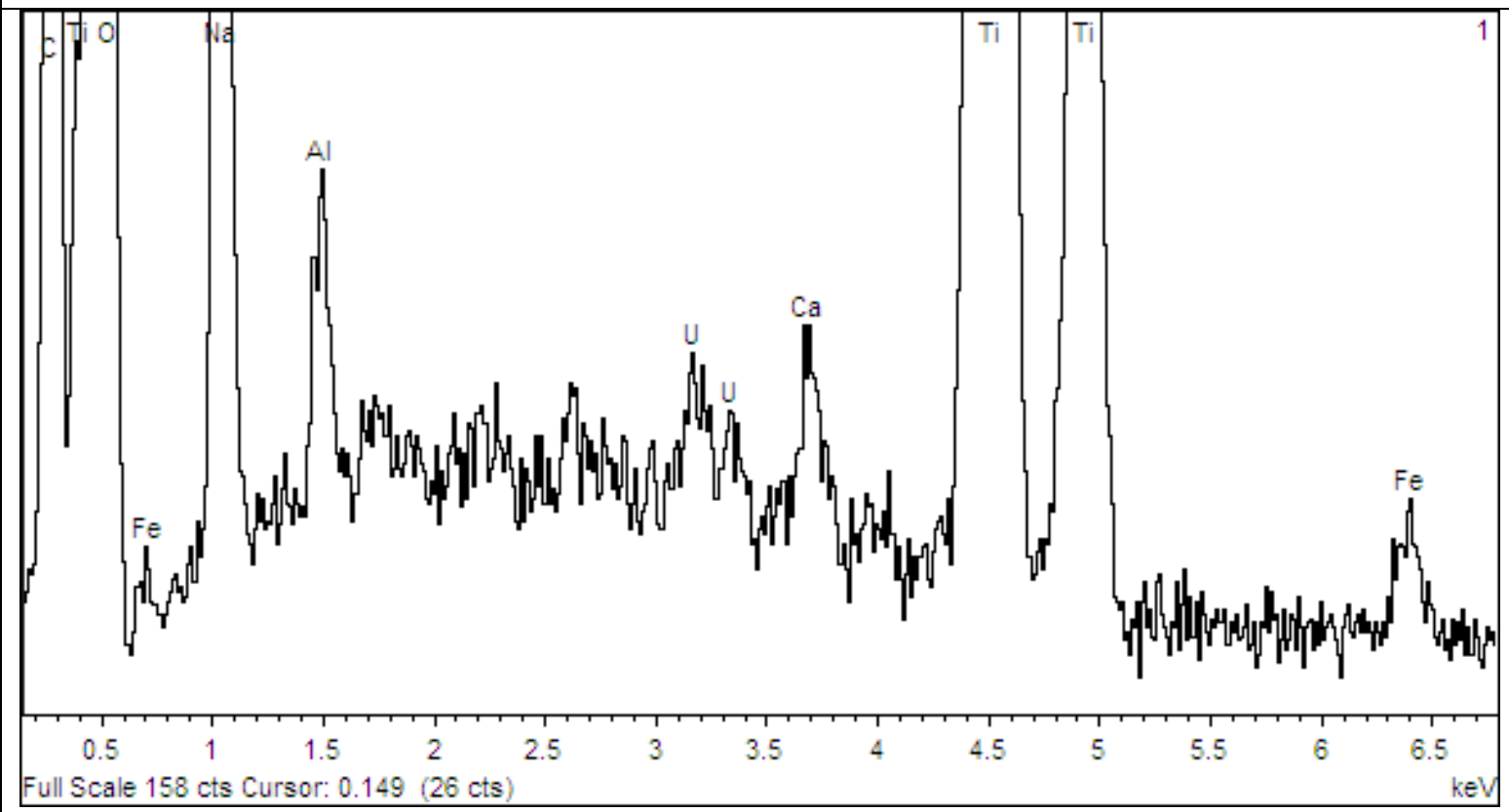

(b)

Figure A- 4. Energy Dispersive Spectroscopy from Figure A- 3 spots labled '1', (a) normal resolution, (b) high resolution. 


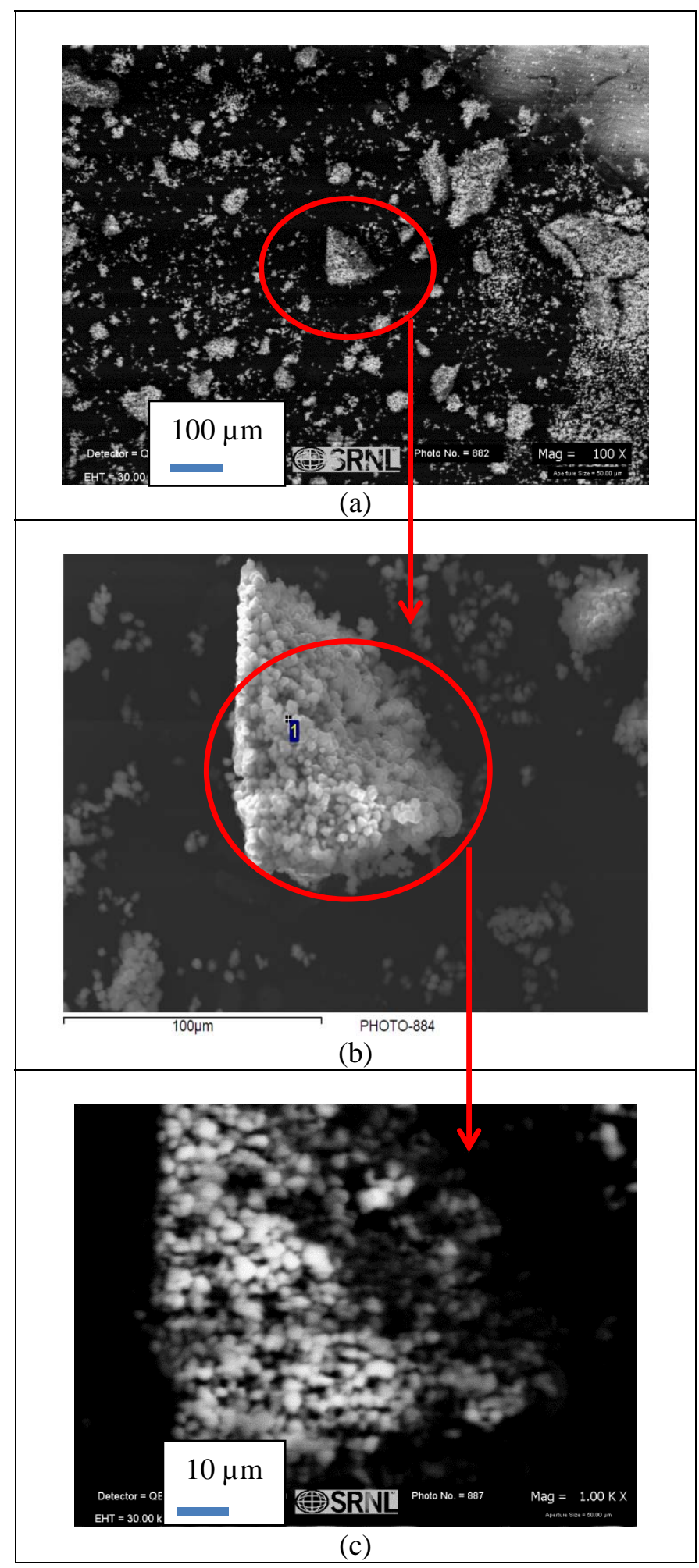

Figure A- 5. (a) 100X magnification SEM of PRFT sample 1 material showing $100 \mu \mathrm{m}$ scale bar; (b) 500X magnification SEM of PRFT sample 1 material showing $100 \mu \mathrm{m}$ scale bar; (c) 1,000X magnification SEM of PRFT sample 1 material showing $10 \mu \mathrm{m}$ scale bar. 


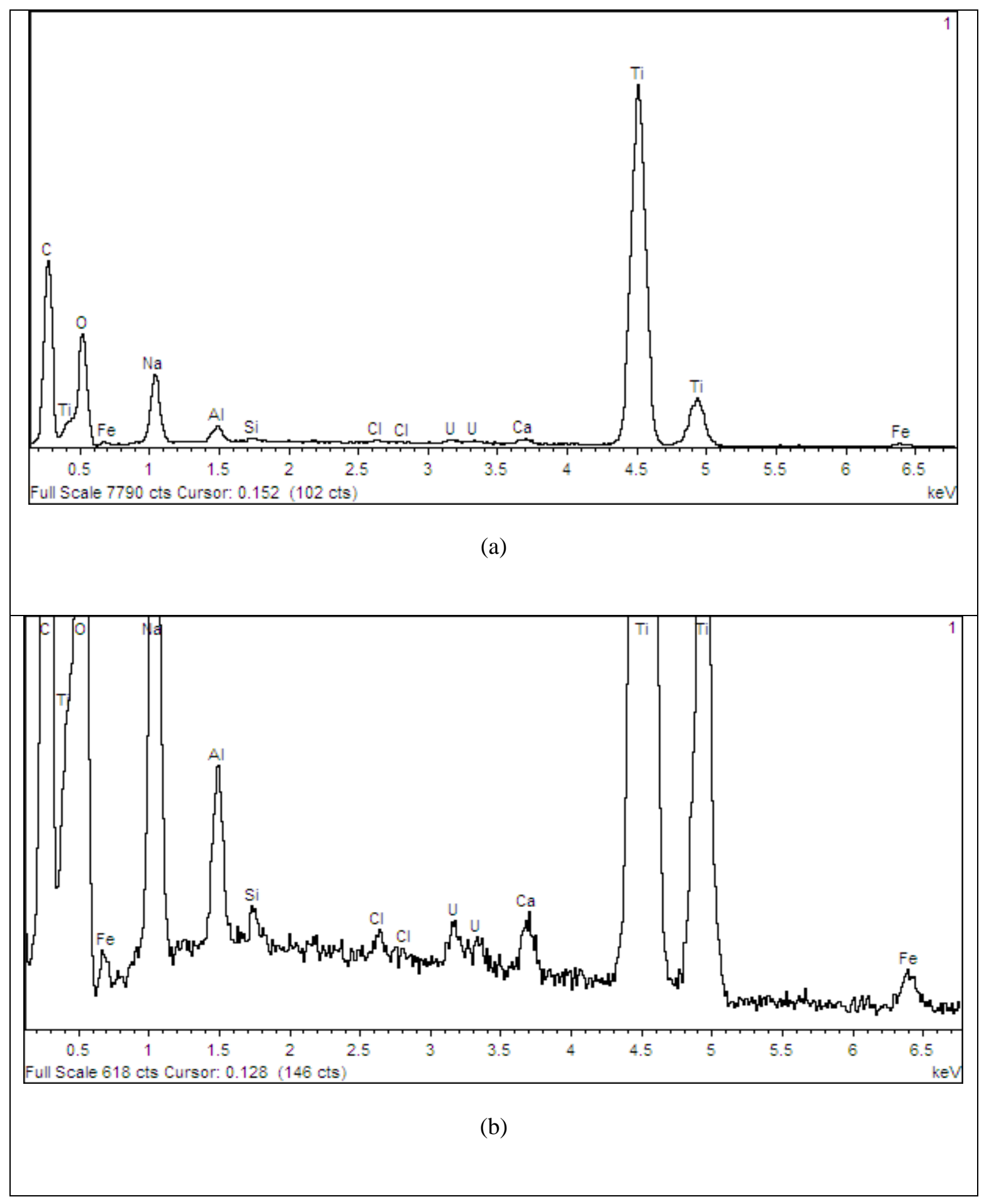

Figure A- 6. Energy Dispersive Spectroscopy from Figure A- 5-b spot labeled '1', (a) normal resolution, (b) high resolution. 


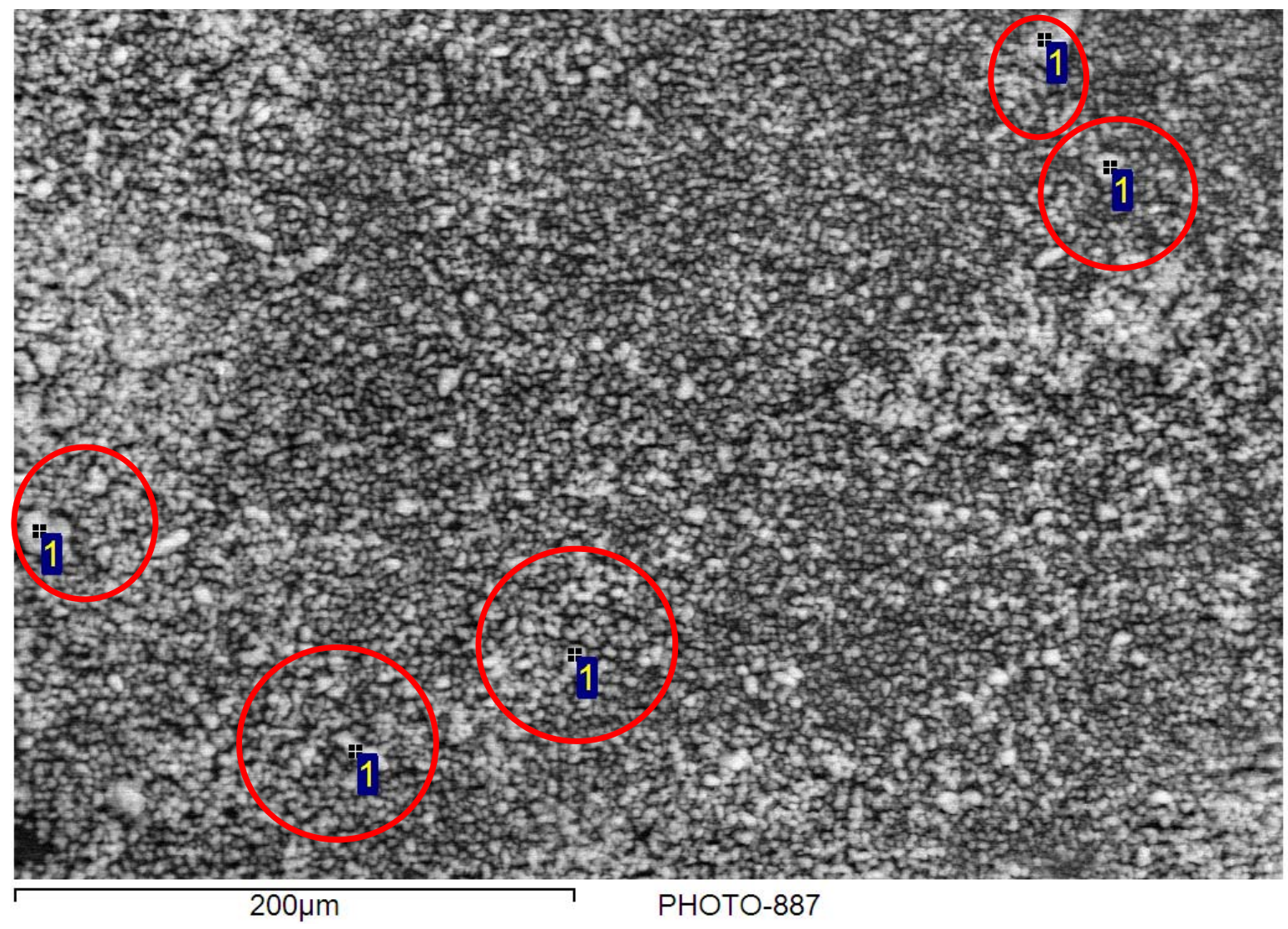

Figure A- 7. A 250X magnification SEM of PRFT sample 1 material showing $200 \mu \mathrm{m}$ scale bar. Regions labeled with a ' 1 ' inside the red circles were analyzed by EDS. 


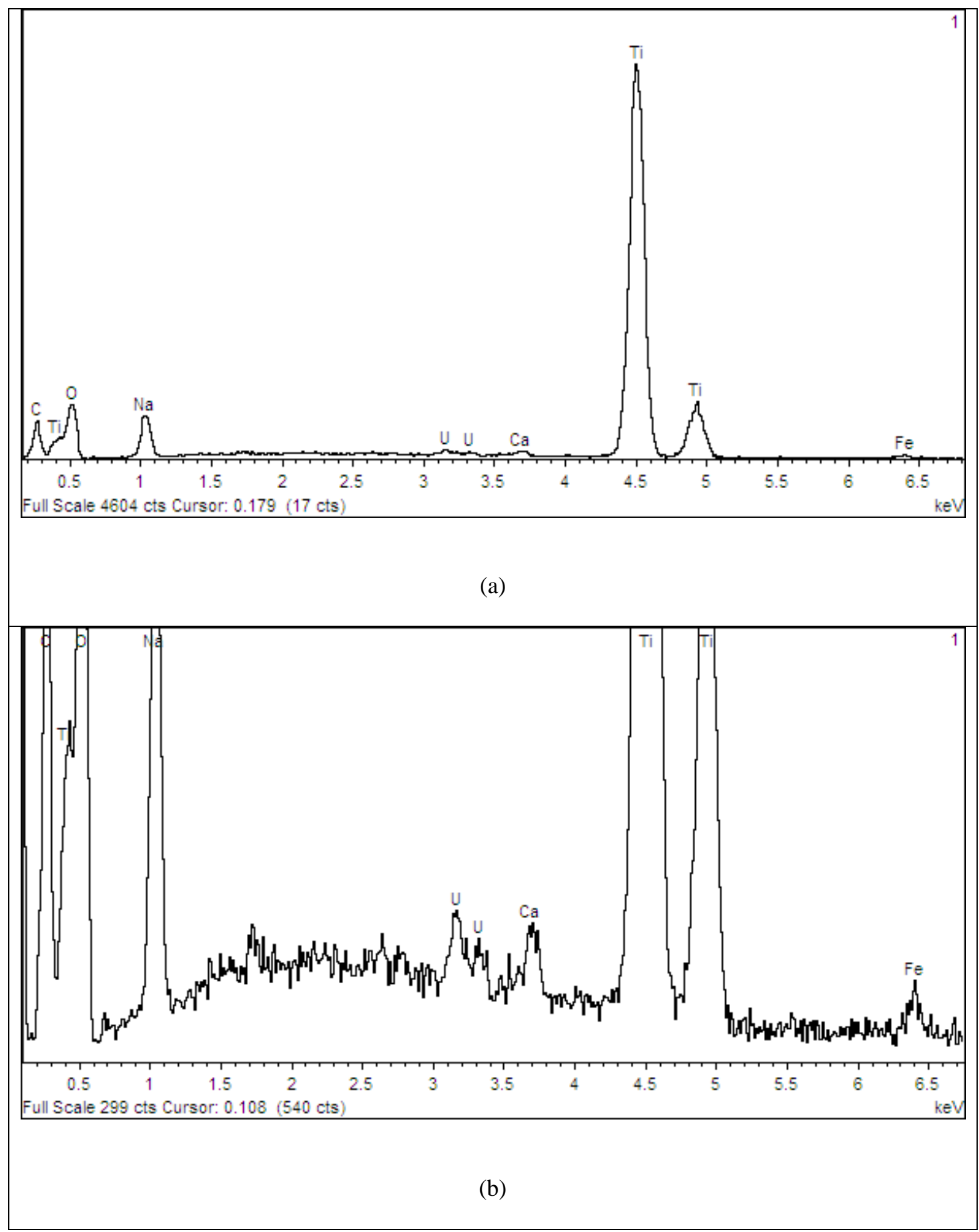

Figure A- 8. Energy Dispersive Spectroscopy from Figure A- 7 spots labeled '1', (a) normal resolution, (b) high resolution. 


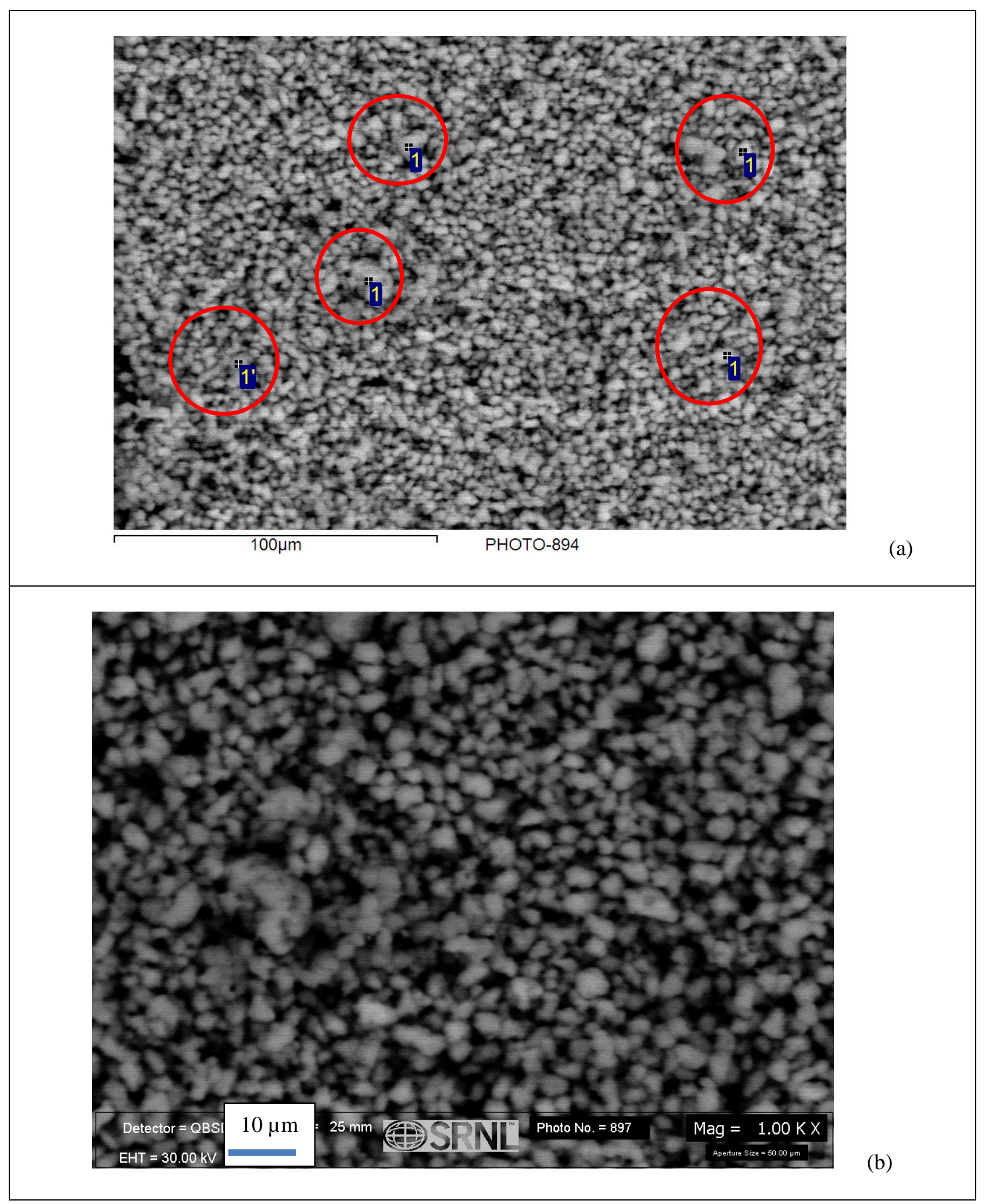

Figure A- 9. SEM of PRFT sample 2 showing (a) 500X magnification with $100 \mu \mathrm{m}$ scale bar and (b) $1,000 X$ magnification with $10 \mu \mathrm{m}$ scale bar. Regions labeled with a ' 1 ' inside the red circles of (a) were analyzed by EDS. 


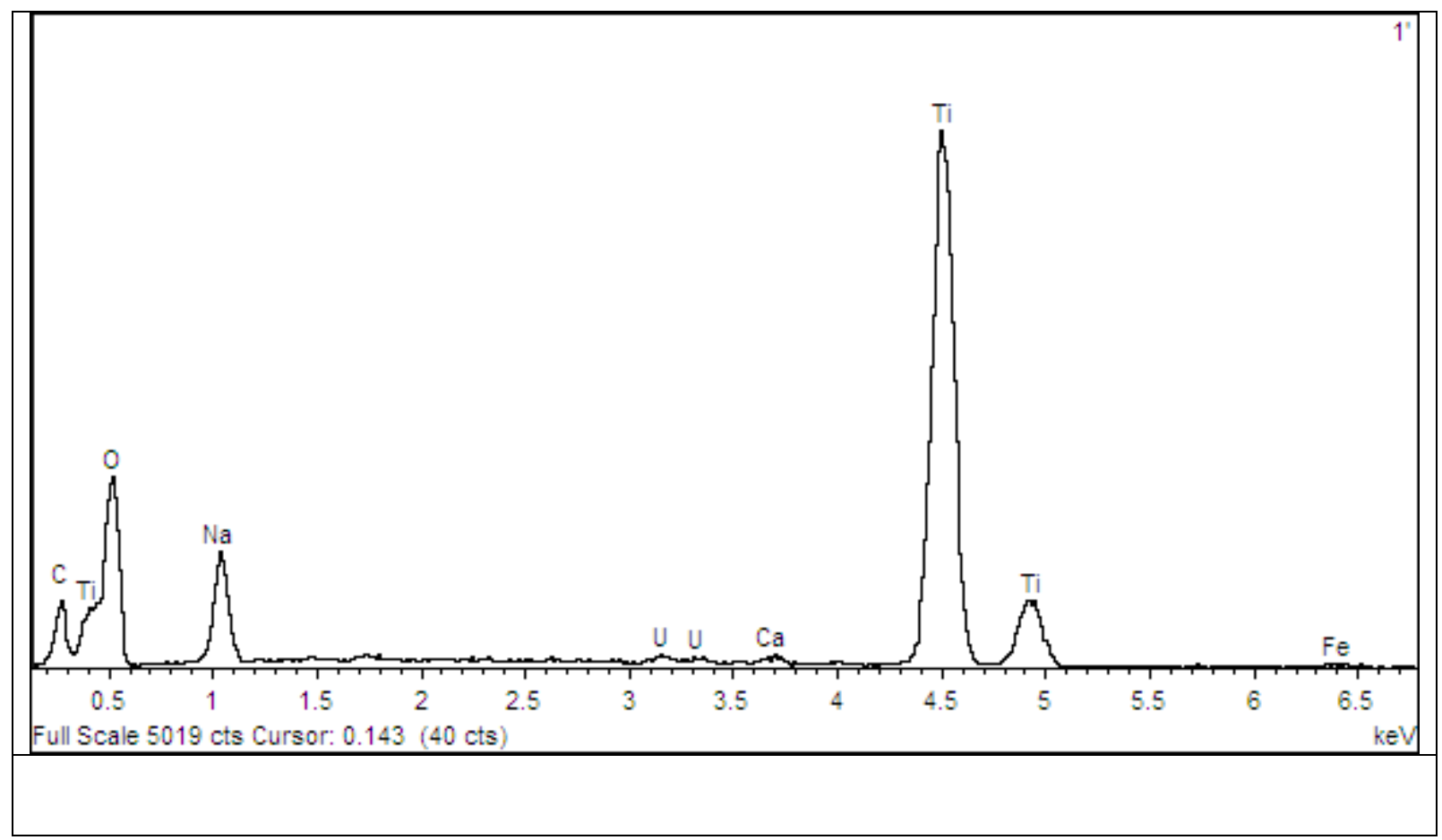

Figure A- 10. Energy Dispersive Spectroscopy from Figure A- 9 spots labeled '1'. 


\section{Distribution:}

S. L. Marra, 773-A

F. M. Pennebaker, 773-42A

T. B. Brown, 773-A

D.H. McGuire, 999-W

S. D. Fink, 773-A

E. N. Hoffman, 999-W

W. R. Wilmarth, 773-A

Records Administration (EDWS)

W. A. Drown, Jr., 773-41A

C. M. Jantzen, 773-A

C. L. Crawford, 773-42A

J. M. Pareizs, 773-A

C. J. Bannochie, 773-42A

S. H. Reboul, 773-42A

C. J. Martino, 773-42A

T. B. Edwards, 999-W

K. M. Fox, 999-W

F. C. Johnson, 999-W

D. P. Lambert, 999-W

J. D. Newell, 999-W

D. K. Peeler, 999-W

M. E Stone, 999-W

J. R. Zamecnik, 999-W

J. W. Amoroso, 999-W

P. R. Jackson, DOE-SR, 703-46A

J. M. Bricker, 704-30S

T. L. Fellinger, 766-H

A. Samadi-Dezfouli, 704-27S

R. N. Hinds, 704-S

E. W. Holtzscheiter, 766-H

J. F. Iaukea, 704-27S

S. C. Smith, 704-27S

R. T. McNew, 704-S

E. J. Freed, 704-S

J. W. Ray, 704-27S

D. C. Sherburne, 704-S

H. H. Elder, 704-27S

J. M. Gillam, 766-H

B. A. Hamm, 766-H

M. T. Keefer, 766-H

H. B. Shah, 766-H

A. R. Shafer, $766 \mathrm{H}$

P. D. Schneider, 210-S 